\title{
The Male Genital Tract in the Era of Highly Active Antiretroviral Therapy (HAART): Implication for Antioxidant Therapy
}

\section{Azu 0O*}

Discipline of Clinical Anatomy, Nelson R Mandela School of Medicine, University of KwaZulu-Natal, Durban 4001, South Africa.

\begin{abstract}
With nearly two decades following the introduction of Highly Active Antiretroviral Therapy (HAART) in the management of HIVIAIDS, tremendous success has been recorded in the control of HIV replication and overal wellbeing and longevity of afflicted patients. But this success has not been complete as HAART strategy still suffers from a myriad of issues, chiefly deleterious side effects owing to oxidative stress-induced cellular injuries.

Pointless to say that this has impeded progress made so far and has left researchers in the continued search for options. With changing trends in fertility concerns of many patients infected with HIV, a gradual but persistent trust towards procreative tendencies of these patients who are still within the reproductive age axis becomes a compelling issue for experts. Numerous research points to the beneficial effects of antioxidant augmentation in HAART especially relevant in the midst of escalated cost of antiretroviral drugs in resource-deprived settings. A continued attempt to elucidate pathophysiological mechanisms involved in HAART-associated oxidative stress-mediated reproductive injuries remains critically important to improving the treatment strategies for this epidemic condition. Therefore, an overview of our current knowledge on HAART induced changes via oxidant-antioxidant pathway becomes pertinent as we unravel the body of knowledge that may be necessary to guide future directions particularly in reproduction.
\end{abstract}

\section{Keywords: HAART; Reproductive tract; Oxidative stress}

Abbreviations: MGT: Male Genital Tract; OS: Oxidative Stress; LPO: Lipid Peroxidation; ROS: Reactive Oxygen Species; HAART: Highly Active Antiretroviral Therapy; HIV: Human Immunodeficiency Virus; ARVDs: AntiRetroViral Drugs; NRTIs: Nucleoside Reverse Transcriptase Inhibitors; NNRTIs: None Nucleoside Reverse Transcriptase Inhibitors; PIs: Protease Inhibitors; CAT: Catalase; SOD: SuperOxide Dismutase; GPx: Glutathione Peroxidase; NF-kB: Nuclear transcription Factor kappa B, mtDNA: Mitochondrial DNA; ATP: Adenosine TriPhosphate; NAC: N-AcetylCysteine; mtDNA mitochondrial DNA; Pol- $\gamma$ : Polymerase gamma

\section{Introductory Comments}

The male genital tract (MGT) comprises anatomically various structures that support the overall function of procreation as well as elimination of waste products via urine in the human species. Though the composition of the structures that perform this unique function varies in nomenclature among mammalian species, they are nonetheless serving the essential role of spermatozoal (production, storage, transport and nutrition) as well as voiding of urine. Component parts of this highly integrated system include the testes and adjoining structures and the accessory glands (prostate, seminal vesicles, bulbourethral gland) with the urethral pathway. Testicular microanatomy is made up of numerous highly coiled tubules, the seminiferous tubules, which makes up over $65 \%$ by volume of the post-pubertal testicles and constitute site for spermatogenesis [1]. However, the entire process of spermatogenesis itself involves series of morphological and biochemical transformation that will eventually result in the formation of a mature sperm cell capable of fertilizing the female counterpart-the ovum. Due to this complexity, various pathologies (infertility, oxidative stress from torsion, cancer, hypogonadism or disorders of spermatogenesis caused by toxicant exposure, varicocele or aging) have been associated with this process targeting various cell types [2]. While the sperm cell plasma membrane is high in polyunsaturated fatty acids (PUFA) making it especially vulnerable to free radical attack [3], it is only recently that cellular redox activity is found to be important for sperm to attain a functionally competent state to fertilize an oocyte [4].

Remarkable variation exists in the mammalian development of the male accessory sex glands [3], the predominant ones being seminal vesicles, prostate and the bulbourethral glands. In rodents, ampullary glands and coagulating glands are also present. In the golden hamster, the main accessory sex glands are made up of the ampullary glands, ventral prostate gland, dorsolateral prostate glands, coagulating glands and seminal vesicles. Apart from providing sperm with a nutritious medium for gamete transfer, these glands secrete antioxidant enzymes such as superoxide dismutase, catalase and glutathione peroxidase as well as free radical scavengers such as Vitamins C and E, hypotaurine, taurine, uric acid and albumin [3]. Studies carried out by various authors have shown that male accessory sex gland secretions are important to fertility in terms of sperm transport, motility acquisition and capacitation in diverse mammalian models and perturbations of which have resulted in diverse pathologies [5-7].

The human immunodeficiency virus (HIV) is the cause of the acquired immune-deficiency syndrome (AIDS). With the introduction of highly specific and effective antiviral regimen referred to as the highly active antiretroviral therapy (HAART), there has been relative decline in morbidity and mortality associated with HIV/AIDS in industrialised countries of the world $[8,9]$. However, besides these positive effects of

*Corresponding author: Azu OO, Discipline of Clinical Anatomy, Nelson R Mandela School of Medicine, University of KwaZulu-Natal, Durban 4001, South Africa, E-mail: azu@ukzn.ac.za

Received August 11, 2012; Accepted September 17, 2012; Published Septembe 19, 2012

Citation: Azu OO (2012) The Male Genital Tract in the Era of Highly Active Antiretroviral Therapy (HAART): Implication for Antioxidant Therapy. J AIDS Clinic Res 3:169. doi:10.4172/2155-6113.1000169

Copyright: ( $) 2012$ Azu OO, et al. This is an open-access article distributed unde the terms of the Creative Commons Attribution License, which permits unrestricted use, distribution, and reproduction in any medium, provided the original author and source are credited. 
HAART on the immune and metabolic changes during HIV infection, compelling evidence suggests that patients infected with HIV are under chronic oxidative stress [8]. More so, the use of HAART itself also inflicts severe deleterious consequences that are mediated via oxidant-antioxidant pathway and this has diminished the enthusiasm generated by HAART [10]. Therefore, the understanding that people infected with HIV, treated with HAART, can benefit from the simple treatment with antioxidants has become supportive with evidence from supplementation with vitamins $[8,9]$. In the light of this information, the aim of this review article is to review current knowledge about antioxidant supplementation in HAART vis-à-vis its interactions in HIV/AIDS patients with special focus on the testicular and spermatogenic indices. Focus on oxidative stress-mediated pathway for HAART-induced reproductive aberrations would be highlighted.

\section{MGT, Oxidative stress, and HAART}

Oxidative stress (OS) in cells and tissues usually refers to increased generation of $\mathrm{O}$ and $\mathrm{H}_{2} \mathrm{O}_{2}$ which can be achieved by raising oxygen concentrations in tissues or adding certain toxins that increase intracellular oxidant formation or activating a large number of phagocytes $\left(\mathrm{O}\right.$ and $\mathrm{H}_{2} \mathrm{O}_{2}$ are produced by activated phagocytes and are essential for the killing of many bacterial strains, but they can do tissue damage when generated in excess) [11].

During the last 25 years, a large body of experimental evidence has accumulated from pharmacological intervention studies that suggest an important role for reactive oxygen species in numerous pathophysiological processes. While a variety of chemical mechanisms of reactive oxygen-induced damage to lipids, proteins, and DNA is fairly well understood; the molecular pathology of oxidant stress-induced tissue injury in vivo remains unclear in most cases [12]. The pathologic phenomenon of oxidative stress (OS) results from an imbalance between the production of reactive oxygen species (ROS) and the defense systems that function to scavenge or destroy them $[13,14]$. In a biological system, cells are constantly exposed to many stimuli, some of which induce various degree of stress on the cells/system that may result to damage of intracellular macromolecules, including proteins, DNA, RNAs and lipids and carbohydrates ultimately leading to cell death $[14,15]$. Therefore, the ROS, which are inevitably produced during the metabolic process, modify various cellular components by oxidation, thus impairing their physiologic function. Their production is enhanced under pathological conditions, such as inflammation and ischemia/reperfusion and is involved in various diseases and aging [16].

HAART usually consist of combinations of NRTIs and protease inhibitors and/or NNRTIs [17]. Recent studies have looked at the fertility indices of HIV seropositive men undergoing treatment with antiretroviral therapy $[18,19]$ and have come up with the result that some HIV medications like the NRTIs (e.g. lamivudine and abacavir) can be toxic to the mitochondria. The understanding is based on the fact that the mitochondrion is the 'power-house' of the sperm cell; hence these drugs target the energy supply and hence compromise fertility of the individual. This has dire implications because if this assertion is confirmed, semen motility would become one of the most sensitive indicators of HAART toxicity as it were. Therefore, emerging counter results from some other authors reveal no difference in semen parameters that may affect fertility following antiretroviral therapy [20]. While acknowledging these discrepancies, it is noteworthy to point out that much of the observations and reports have been based on different sample populations or experimental cohorts and under diverse aetio-pathological underpins that might have influenced the outcomes. However, in a previous review [17], it was noted that the association of HAART and sexual dysfunction in seropositive HIV patients remains a subject of intense research amongst researchers. It is reasonable to believe that this argument may still remain unresolved till such a time when exhaustive tools would have been employed to assess the MGT morphologically and correlate changes with other associated parameters of fertility.

Semen quality is a key factor determining reproductive success in men [21] especially as with chronic diseases [22] and as such significant attention has been focused on all aspects that may negatively impact on the overall effectiveness and efficiency of this function. Up till recently however, andrological perturbations have been utilized as the hallmark of sexual dysfunction in HIV medicine [23]. Physiologically, reactive oxygen species (ROS) are required by spermatozoa to attain functional maturity. These low levels of ROS are essential for normal fertilization, capacitation, hyperactivation, motility and acrosome reaction [24]. Spermatozoa acquire fertilizing ability after capacitation occurs in a favourable environment [25]. Capacitation is a process that prepares the spermatozoa for interaction with oocyte leading to fertilization and during this process the concentrations of intracellular calcium, ROS and tyrosine kinase increase, resulting in an increased formation of cyclic adenosine monophosphate. A high concentration of cyclic adenosine monophosphate facilitates the spermatozoa to acquire high motility known as hyperactivation [26]. Pathologically, toxicant injury affecting male reproductive competencies have directly or indirectly affected any of the mechanisms or processes that regulate spermatozoal motility. Therefore, potent drugs utilized in HAART have targeted the mitochondria [27] thereby leading to various spermatogenic abnormalities, teratospermia and asthernozoospermia [19].

\section{Reactive oxygen species (ROS) and lipid peroxidation}

Reactive oxygen species (ROS) are highly reactive forms of oxygen, free radicals (FR), which are short-lived intermediates containing one or more unpaired electrons. They include an array that has superoxide anion $\left(\mathrm{O}^{2-}\right)$, hydrogen peroxide $\left(\mathrm{H}_{2} \mathrm{O}_{2}\right)$, hydroxyl radical $(\mathrm{OH})$, nitric oxide $(\mathrm{NO})$, hypochlorous acid $(\mathrm{ClOH})$, peroxide $(\mathrm{ROOH})$ and peroxynitrite (ONOO-) [28-30]. These highly reactive species are generated in a number of conditions by cellular and acellular mechanisms and have been implicated as an aetiological factor of a wide range of diseases including HIV infection [31] and HAARTassociated mechanisms [32,33]. While the pathophysiology of male reproductive tract and spermatozoa is currently well understood, the major antioxidative and redox systems that are currently assumed to play roles in the male reproductive system during HAART remains a subject for continuous debate. The chemistry of autoxidation in general, and of lipids in particular (lipid peroxidation), is now well-understood. Oxygen reacts with oxidizable substrates, such as polyunsaturated lipids, via the intermediacy of transient free radical species that may be formed in many different ways. A potentially significant source of free radicals, and an example of how free radical reactions are initiated, is the transition-metal (e.g. iron $(\mathrm{Fe})$ or Copper $(\mathrm{Cu})$-catalysed decomposition of the hydroperoxide products of lipid oxidation (i.e. $\mathrm{H}_{2} \mathrm{O}_{2}$ or lipid hydroperoxides (shown in the reaction below) [34,35].

$$
\mathrm{LOOH}(\mathrm{HOOH})+\mathrm{Fe}^{2+} \rightarrow \text { LO. }(\mathrm{HO} .)+\mathrm{HO}-+\mathrm{Fe}^{3+}
$$

Transition metal ions, (mainly iron) generate highly reactive hydroxyl radicals by Fenton's reaction [34]. These radicals stimulate lipid peroxidation by decomposing the peroxides into peroxyl and alkoxyl radicals, and triggering a chain reaction of lipid peroxidation. Human semen contains metal chelators such as transferrin, lactoferrin 
and ceruloplasmin that reduce lipid peroxidation of the sperm plasma membrane, protecting its integrity [29].

However, reactive oxygen species can participate in recruitment of inflammatory cells by up-regulation of adhesion molecules and generation of chemotactic factors, and are necessary for proteasemediated cell injury in vivo. ROS can also scavenge other biologically active molecules (e.g., nitric oxide), thereby modulating indirectly their effector cells [11]. The implication of this is that once formed, ROS participate in a number of reactions, yielding additional free radicals such as hydrogen peroxide, peroxynitrite, or hypochlorous acid [36]. In towing this line, researchers are now of the thought of ROS as a signalling molecule that are mobilised in response to various stimuli. ROS modulates $\mathrm{Ca}^{2}$ signalling and protein phosphorylation events and thereby function as regulators of various biologic processes such as gene expression, cell growth, differentiation, chemotaxis and cell death [37]. The free radicals in HIV infection could result also from nonenzymatic protein oxidation and the subsequent oxidative degradation of glycated proteins [30].

Although polyunsaturated lipids are the most vulnerable and most abundant target susceptible to free radical attack, the free radical damage may spread beyond the immediate lipid environment to include structural and functional damage to components containing proteins, carbohydrates and DNA. The damage may be affected directly by the radicals themselves or through the generation of labile lipid peroxidation products, e.g. aldehydes.

\section{Generation of reactive Oxygen Species (ROS)}

Reproduction is a fundamental process that allows living organisms to preserve their progeny and evolve by transmitting genes. However, metabolism, which is supported by sex steroid hormones, is highly activated during spermatogenesis, indicating that the reproductive system itself generates high levels of ROS [38]. The present day combination therapy-HAART utilizes seven classes of drugs that target various stages in the life cycle of HIV. These include nucleoside reverse transcriptase inhibitors (NRTIs e.g. zidovudine), nucleotide reverse transcriptase inhibitors (NtRTIs e.g. tenofovir diisoproxil fumarate), non-nucleoside reverse transcriptase inhibitors (NNRTIs e.g. nevirapine), protease inhibitors (PIs e.g. indinavir), fusion inhibitors (FIs e.g. enfuvirtide), co-receptor inhibitors (CRIs e.g. maraviroc) and Integrase Inhibitors (INIs e.g. raltegravir) (Kumari and Singh, 2012). ROS can be produced by oxidases in the endoplasmic reticulum (cytochrome P450s), the plasma membrane (NADPH oxidases) and the mitochondria (electron transport system) [39]. Table 1 shows a summary of the effects of HAART on oxidative stress status in MGT.

We had previously demonstrated that cytotoxic drugs (cisplatinum) generate free radicals that target rapidly replicating spermatogenic cells as part of their mechanism of action [40]. Laurent et al. [41] reported that the three commonly used fixed-dose combination therapy for HAART therapeutic regimes used on patients (lamivudine, stavudine and nevirapine) lowered plasma concentration of the antioxidant Vitamin $\mathrm{C}$ and higher thiobarbituric acid reactive substances (TBARs) (a marker for lipid peroxidation). Others studies reported that HAART medications may increase oxidative stress levels above and beyond levels caused by the virus itself [30]. It is therefore possible that, the observed effect may be a consequence of this association. In HIV infection, reactive oxygen species may enhance viral replication by activating nuclear transcription factors, which ultimately lead to viral gene expression. Further, in HIV-infected adults, zidovudine was shown to promote oxidative damage to DNA, a process that was reversible with vitamin $\mathrm{C}$ and vitamin E supplementation [42]. Several pre-HAART studies found that both asymptomatic HIV-infected individuals and AIDS patients had higher levels of oxidative stress, as indicated by increased plasma metabolites of lipid peroxidation and/ or reduced antioxidant levels, compared with healthy controls [43]. It is plausible thence that HAART may induce (i) an increase in oxidant generation, (ii) a decrease in anti-oxidant protection, or (iii) a failure to repair oxidative damage. Oxidative stress-mediated cell damage occurs, in part, via reactive oxygen species (ROS) [30].

\begin{tabular}{|c|c|c|c|c|c|}
\hline Drug & Effect(s) & $\begin{array}{l}\text { Nature of experiment/ } \\
\text { no of patients }\end{array}$ & Dose & Duration & References \\
\hline HAART & $\begin{array}{l}\text { Reduction in the plasma concentration of protein } \\
\text { sulfhydrl groups and } \\
\text { vitamin C }\end{array}$ & 85 HIV positive patients & $\begin{array}{l}\text { Stavudin }(80 \mathrm{mg})+ \\
\text { Lamivudin }(600 \mathrm{mg})+ \\
\text { Nevirapin }+(400 \mathrm{mg}) \\
\text { zidovudine }(600 \mathrm{mg})\end{array}$ & - & Ngondi et al. [30] \\
\hline $\begin{array}{l}\text { One PI and two } \\
\text { NRTIs; } \\
\text { One NNRTI and two } \\
\text { NRTI }\end{array}$ & $\begin{array}{l}\text { Decreased antioxidant status in HIV-1 treated } \\
\text { group. } \\
\text { Significantly higher oxidative status }\end{array}$ & $\begin{array}{l}116 \text { HIV-1-infected patients } \\
\text { (86 HAART-treated and } 30 \\
\text { untreated), and } 46 \text { HIV- } \\
\text { negative control. }\end{array}$ & - & $\begin{array}{l}\text { average of } 6.3 \\
\pm 2.2 \text { years }\end{array}$ & Mandas et al. [204] \\
\hline EFV (NNRTI) & $\begin{array}{l}\text { Triggered apoptosis via the intrinsic pathway. } \\
\text { Inducing an increase in mitochondrial superoxide } \\
\text { production, reduction in cellular glutathione content. }\end{array}$ & $\begin{array}{l}\text { In vitro studies human } \\
\text { hepatic cells. }\end{array}$ & $(10,25$ and $50 \mathrm{mM})$ & $\begin{array}{l}72 \text { hours } \\
\text { incubation }\end{array}$ & Apostolova et al. [48] \\
\hline PI (nelfinavir NFV) & Induces oxidative stress by increased ROS production & $\begin{array}{l}\text { In vitro studies; cell } \\
\text { culture }\end{array}$ & $30 \mu \mathrm{mol} / \mathrm{l} \mathrm{NFV}$ & 18 hours & Ben-Romano et al. [205] \\
\hline $\begin{array}{l}\text { Nevirapine (NVP; } \\
\text { Viramune) }\end{array}$ & $\begin{array}{l}\text { Significant decrease in the activities of hepatic, renal } \\
\text { and testicular superoxide dismutase and catalase. } \\
\text { Induced oxidative stress with corresponding decline } \\
\text { in antioxidant status of the rats. }\end{array}$ & Twenty-one rats & $\begin{array}{l}18 \text { and } 36 \mathrm{mg} / \mathrm{kg} \text { body } \\
\text { weight }\end{array}$ & $\begin{array}{l}4 \text { consecutive } \\
\text { weeks. }\end{array}$ & Adaramoye et al. [200] \\
\hline $\begin{array}{l}\text { HIV patients } \\
\text { undergoing HAART }\end{array}$ & $\begin{array}{l}\text { Significant decrease in the levels of GSH in both } \\
\text { naive and HIV-TB co-infected patients and HIV } \\
\text { patients on HAART. } \\
\text { Lower antioxidant level and higher MDA in naive } \\
\text { and HIV-TB co-infected patients as compared to HIV } \\
\text { patients on HAART and the seronegative patients. }\end{array}$ & $\begin{array}{l}100 \text { consenting subjects } \\
\text { (aged } 18 \text { to } 40 \text { years) } \\
\text { patients on HAART }\end{array}$ & Standard dose & - & Awodele et al. [206] \\
\hline Saquinavir & $\begin{array}{l}\text { Decreased sperm motility in vitro and negatively } \\
\text { affects acrosome reaction }\end{array}$ & & & & Ahmad et al. [207] \\
\hline
\end{tabular}

Table 1: Summary of effects of HAART on oxidative status in MGT/semen. 


\section{Oxidative stress in MGT and HAART}

Semen is composed of cells and secretions from the testes, epididymis, prostate, seminal vesicles and bulbo-urethral glands. The extent of involvement of these structures in HIV pathogenesis and therapy remains a subject of current debate as a result of viral compartmentalisation [44].

However, the spermatozoon is particularly susceptible to oxidative damage due to its unique structural composition of highly specific polyunsaturated fatty acids (PUFAs), plasmalogenes and sphingomyelins [29]. In the process of maturation spermatozoa extrude cytoplasm. Since cytoplasm is the major source of antioxidants, lack of cytoplasm causes a deficiency in antioxidant defense. Ironically, when this process is hindered, residual cytoplasm forms a cytoplasmic droplet in the sperm mid region [14]. The issue of MGT compartmentalisation has been argued in Lowe et al. [45] but the implication here is that in order to reach seminal compartments, compounds presumably must either fully penetrate lipid barriers or penetrate the lipid membrane of secretory cells for packaging and secretion. By implication, the more lipid soluble the compound, the greater the partition coefficient and the greater the compound's ability to cross these barriers [46].

Polyunsaturated fatty acids, which are major components of cell membranes, can also undergo free radical attack, producing lipid peroxidation products like malondialdehyde (MDA) and 4-hydroxynonenal. Under normal circumstances, the body is protected from such damage by a careful balance between pro-oxidants and antioxidants [30].

Due to the special characteristics of HIV disease itself, the development of antiretroviral drugs in the past was particularly rapid and focused essentially on clinical efficacy ( to reduce associated mortality with the scourge). But as the disease has become a controlled and manageable chronic condition [47], increasing emphasis has been placed on the long-term adverse effects caused by the therapy on patients [48]. As the mitochondria has become a major target for druginduced cytotoxicity occurring via a wide range of mechanisms such as inhibition or uncoupling of oxidative phosphorylation, oxidative stress/ or opening of mitochondrial permeability transition pore [27], many of the HAART agents have come under the search light of researchers with the view to unravelling these pathways.

Pathways of generation of ROS by HIV and HAART: ROS can be generated by cellular and acellular mechanisms such as leucocytes during HIV infection [31] and drug toxicity [27,49] respectively. The disruption of the delicate balance between pro-and antioxidants has been implicated in the pathophysiology of many diseases affecting the MGT and AIDS [51].

HIV weakens the human immune system and research have shown that OS may have a principal contributory role to both the expression of HIV and the development of AIDS [43,52]. With the insidious nature of AIDS, advanced cases of HIV infection renders the individual susceptible to opportunistic infections. Since cellular redox status is a normal physiological variable, any imbalance may elicit cellular response through proliferation, transcriptional activation or apoptosis [53]. In this line, investigations in the recent years have focused on the interactions between HIV, HAART and mitochondria [54] and HIV itself might be capable of causing OS [55]. Putative pathways for the generations of ROS thus leading to OS and toxicity of HAART relies on mitochondrial-related perturbations that manifests in many side effects such as hepatic failure and lactic acidosis [55]. Bearing this in mind, several molecular and cellular techniques and different in vitro models are currently available to analyse the mitochondria. Many researchers are utilising a variety of methods in the investigation of various compounds, drugs and cells from patients treated under different therapeutic protocols [54]. However, despite intense interest in finding a solution to this problem with significant advances towards this end, a unifying, mechanistic, pharmacologically relevant understanding of the pathophysiological events leading to mitochondrial toxicity in humans remains elusive.

Several hypotheses have been proposed by various researchers to delineate the mechanisms involved in the pathogenesis of HIV/ HAART-associated OS injuries. However, the major HAART culprits remain the NRTIs and PIs $[55,28]$ and three related mechanisms are believed to be operative in mediating the toxicities; energy deprivation, mitochondrial OS and thence mitochondrial DNA (mtDNA) damage. Together, these form the 'mitochondrial dysfunction hypothesis' [55] which is analogous to the approach examining defects in genetic mitochondrial illnesses in which the defective mitochondrial gene product, OS and the environment contribute to disease pathogenesis [56]. It is believed that NRTIs especially zalcitabine (ddC), didanosine (ddI) and stavudine (d4T) are potent inhibitors of DNA polymerase gamma and this is supported by data from basic and clinical studies [57-59]. The inhibition of polymerase gamma, as postulated by Lewis et al. [60], involves four different mechanisms which encompasses their effects as: (a) mtDNA chain terminators (once incorporated into a growing strand, DNA replication is abruptly halted); (b) competitive inhibitors (competing with natural nucleotides to be incorporated into growing DNA chains by polymerase gamma); (c) inductors of errors in fidelity of mtDNA replication inhibiting the exonucleolytic proofreading function of polymerase gamma and (d) contributors to the decrease of mtDNA reparatory exonuclease activity (resisting exonucleolytic removal by exonuclease activity of polymerase gamma because of lack of group $3 \mathrm{OH}$ in NRTIs.

PIs do not seem to have the above toxic effects as there are able to inhibit apoptosis of both infected and uninfected T cells; hence suggesting that underlying this effect is associated with their ability to halt mitochondrial modifications occurring in the execution phase of apoptosis [61,62]. This observation contrasts other studies using cell models and molecular biology techniques which shows that mitochondrial damage can be caused by infection with HIV per se. Somasundaran et al. [63] studied the intracellular distribution of HIV1 RNA transcripts in infected cells using in situ hybridization and found a significantly increased amounts of viral RNA in mitochondria relative to the cytoplasm and nucleus, suggesting that HIV RNA import into mitochondria can compromise mitochondrial function that may ultimately lead to cell death via OS or other pathways. It becomes plausible therefore that reductions in mtDNA may be caused by HIV infection alone and precede the use of NRTIs (as reported earlier); this raises the possibility that HIV directly or via cytokines released in response to HIV infection or during the immune reconstitution may injure the mitochondria, making them vulnerable to the effects of NRTIs [54].

In the mitochondrial dysfunction hypothesis $(\mathrm{MDH})$, it is believed that inhibition of DNA pol- $\gamma$, the sole DNA polymerase found in the mitochondria responsible for the replication and repair of mtDNA, results in declines in mtDNA copies which in turn cause decreases in synthesis of adequate proteins that are essential for oxidative phosphorylation (OXPHOS). Disruption of OXPHOS leads to energy loss (decrease in adenosine triphosphate (ATP) production) and an increase in electron leakage from the electron-transport chain thus 
increasing the production of ROS [55,64-66]. ROS sets off a cascade of OS-mediated damage seen in many experimental and clinical work e.g., skeletal injuries in mice treated with AZT (de la Asuncion et al., 1999), rats [50] and cell cultures [67].

The mitochondria are logical targets for OS based on their ability to generate FR, hence may be primarily involved also in OS associated with AIDS treatment [68]. Mitochondrial OXPHOS produces ROS under normal physiological conditions as electrons leak out of the electron transport chain forming superoxide radicals instead of water $[69,70]$. Mitochondrial hydrogen peroxide is also rapidly formed from superoxide by dismutation or by mitochondrial manganese superoxide dismutase. With this process, more hydroxyl radicals are also formed at sites where superoxide and hydrogen peroxide are formed in the mitochondria [71]. Ultimately, the FR generated all combine to target mitochondrial proteins, lipids and DNA resulting in a dysfunction [72,73]. Interestingly, the mitochondria contains antioxidant enzymes to protect it against ROS; the manganese superoxide dismutase enzyme catalyses the dismutation of superoxide into hydrogen peroxide and oxygen. The former is a FR capable of eliciting cellular injuries as well [74] but is eliminated by the endogenous glutathione peroxidase which converts it to water and oxidised glutathione [75]. Glutathione reductase recycles the oxidised form of glutathione and together, these enzyme systems prevent the exacerbation of the OS cascade thus maintaining a healthy cellular status/balance [76]. This strict maintenance of this status is critical in the MGT as well as the blood brain barrier (BBB) especially due to the high composition of polyunsaturated fatty acids (PUFA) which are ready targets of these ROS [68] in sperm cell membrane as well as those of the BBB.

In further explanation of the $\mathrm{MDH}$, one must bear in mind that the DNA pol- $\gamma$ is highly processive allowing for a very high rate of replication in one binding event [77]. The consequence of this is that deletion mutants may be replicated faster and more efficiently than the native mtDNA counterparts $[77,78]$. Thus, the increasing abundance of the defective mtDNA culminates to a point, a threshold, where energy depletion becomes very apparent and manifested. These specific mitochondrial energy depletion sequelae is thought to be the initial first step in the process of MDH and incorporates the DNA pol- $\gamma$ hypothesis advanced earlier by Lewis and Dalakas [79]. Energy deprivation is probably the initiating step of NRTI toxicity relating to decreased energy abundance in tissues like the heart or to a decreased abundance of normal functioning mitochondria [55]. Nonetheless, they continue to be debate as to the pathway that may be responsible for certain associated pathologies in HAART. For instance, it is adduced that lipodystrophy caused by NRTIs (d4T, AZT and abacavir) may arise due to mitochondrial toxicity-induced apoptosis rather than necrosis, since the loss of fat is neither painful nor inflammatory [80]. Also, results from studies by Manda et al. [68] provide support that AZT + indinavir (IDV)-treated hCMEC/D3 cells also were undergoing apoptosis.

In the second step of the MDH, OS is shown to impact significantly on the energy status following mtDNA alterations [31] via the generation of ROS. Nitric oxide (NO), another potent ROS, from the calcium-calmodulin-dependent and calcium-independent (inducible) forms of nitric oxide synthase contributes to the repertoire of FR that can be generated. However, its action is greatly enhanced by reaction with superoxide forming peroxynitrite [81]. But it is the protonation and decomposition of peroxynitrite to more reactive species that exacerbates the toxicity of NO to DNA [82]. Various studies on ddC and AZT in rats have demonstrated the cardiotoxic effects of these HAART agents via OS-mediated mechanisms [49,50]. Saquinar protects mesangial cells from apoptosis but fails to protect against NO triggered cell death. This is despite the fact that signals for ROS and NO are known to overlap and produce antagonistic as well as synergistic effects [83]. Recently, it is now thought that ROS may actually be acting as signalling molecules mobilized in response to various stimuli. They modulate $\mathrm{Ca}^{2+}$ signalling and protein phosphorylation events thereby function as regulators of diverse biologic processes like cell growth and differentiation, chemotaxis and cell death [84,37].

The third step in the MDH is mutations of mtDNA which can result from oxidative damage to DNA bases causing strand breaks and degradation of deoxyribose [85]. Research has shown that mtDNA of rat liver has more than 100 times the level of oxidative damage than does nuclear DNA possibly due to; (i) lack of own repair enzymes for mtDNA error excision, (ii) a lack of histones protecting mtDNA and (iii) a subcellular proximity of mtDNA to oxidants [55]. It seems plausible therefore that during any given oxidative event, the mtDNA will sustain more damage than nuclear DNA [86], in addition to the fact that the efficiency of the repair system is doubted. While this may not be the only pathway, it is also possible that other mechanisms are involved in mediating NRTI toxicity, like the inhibition of protein glycosylation [87]. Since 13 components of the respiratory chain are encoded by the mammalian mitochondrial genome, mutations in the mtDNA cripple the oxidative energy production of the cell, with a consequent decrease in ATP production and generation of ROS. Decreased mtDNA abundance impairs the mitochondria's ability to synthesis these 13 proteins with consequent energy deprivation and tissue dysfunction [39]. Deletions in mtDNA can also lead to the generation of ROS [88]. It is likely that newer agents in HAART regimes may offer new opportunities to explore toxic mechanisms in the years ahead as this would significantly contribute towards broadening the scope of less toxic antiretroviral drugs.

Implications of cellular stress: OS stimulates inflammatory response by activating particularly the redox sensitive nuclear factor (NF)-кB which leads to activation of tumour necrosis factor (TNF)- $а$ and generation of various inflammatory cyto- and chemokines $[89,90]$. Cellular stress response is a reaction to changes or fluctuations of extracellular conditions that damage the structure and function of macromolecules. Different stressors trigger different cellular responses, namely induce cell repair mechanisms, and induce cell responses that result in temporary adaptation to some stressors, induce autophagy or trigger cell death. Inability to repair the damage or exposure to prolonged stress may contribute to aging. Persistent cell stress often enhances susceptibility to cancer and aging-associated diseases [15]. Several investigators have recently proposed that apoptosis, initiated by oxidative stress, is the direct cause of lymphocyte loss in patients infected with HIV $[84,91]$. However, the mechanisms that directly trigger the apoptosis are still unclear. One of the biochemical mechanisms of apoptotic death of cells may be unrepaired DNA damage. There are indications that oxidative damage to DNA induces apoptosis in murine T-cell hybridoma [92] and in lymphocytes [93]. Modified DNA bases that were found at high level in the lymphocytes of HIV-infected patients may lead to apoptosis.

Cytotoxic drugs disturb oxidant-antioxidant balance and the oxidative damage to the sperm, testis and genetic materials is thought to be responsible for the serious effects on male fertility. The sperm cells are extremely sensitive to free radical-mediated damage due to active generation of free radicals, lack of defensive enzymes and high concentration of polyunsaturated fatty acids $[29,14]$. Without proper membrane fluidity, enzymes are activated which can lead to impaired 
motility, abnormal structure, loss of viability and death of spermatozoa. These factors make the health of spermatozoa critically dependent upon antioxidants [94].

Decreases in ejaculate volume and increases in semen $\mathrm{pH}$ may be due to reduced accessory gland secretions or ejaculatory dysfunction. Dysfunction of the prostate and seminal vesicles, which are responsible for about $90-95 \%$ of the ejaculate volume, could be due to past or silent inflammation or infection, virus cell gland colonization or to the effects of ART drugs present in the genital tract [95-97]. Decreased motility may be due to viral effects on spermatozoa, abnormal seminal plasma composition, and changes in spermatozoal metabolism due to ART. Taken together, these aberrations are capable of triggering consequential alterations that may jeopardise the fertility capabilities of the patient, who may after all, also be desirous of having a normal reproductive life.

Various studies have demonstrated a relationship between mitochondria and sperm motility [98-101]. As several ARTs have mitochondrial toxicity $[79,102,103]$, the observed changes in motility could be due to the ART itself. A report of increased frequency of multiple DNA deletions in the sperm of patients receiving HAART for more than 12 months supports this hypothesis [104]. HIV- induced oxidative damage is influenced by the extent of oxidative stress and the activity of the body's antioxidant defences which include dietary and non-dietary antioxidants and antioxidant enzymes.

ROS are highly reactive molecules with unpaired electrons that are generated in normal physiological processes or via external stress such as ultraviolet light, ionizing irradiation, and DNA-damaging drugs. Cellular defences to ROS include antioxidant scavengers, such as ascorbate, glutathione, and thioredoxin, and antioxidant enzymes, such as superoxide dismutase, catalase, glutathione peroxidase, and thioredoxin reductase [105]. The proliferation of germ cells is normally excessive and the tightly regulated system of physiological apoptosis optimises the output of germ cells to a level sustainable by the seminiferous epithelium. Therefore, both deficient and excessive apoptosis can result in decreased sperm output [106] and various conditions of oligospermia, azoospermia and asthernozoospermia may ensue with consequent sub-(in) fertility.

\section{Antioxidant Defense System in the MGT and HAART}

Nutritional status has been demonstrated to be an important predictor of HIV-related mortality [107,108]. Current discuss on the possible beneficial effects of augmentation of HIV patients undergoing antiretroviral therapy with nutritional supplements and vitamins has produced diverse views based on the reports from various authors. But the general understanding is based on the fact that HAART-generated free radicals can be mopped-up by endogenous antioxidants (which in the case of HIV sero-positive patients are already depleted) or supplementation with exogenous antioxidant modalities. However, there seem to be discordances as to what is the accepted opinion of experts concerning antioxidant intervention in HAART on the standpoint that much of the evidence has been limited to animal models and purely mechanistic hypotheses $[109,110]$. Ngondi et al. [30] postulates that although there are several known side effects of HIV/AIDS medications, like lipodystrophy, an increase in the risk of cardiovascular disease etc.; there is not sufficient evidence to substantiate the role of free radicals in mediated oxidative injury in HIV/AIDS infection. While Lee et al. and Slain et al. [111,112] believe that limited studies have found a reduction in antiretroviral concentrations with use of antioxidant vitamin $\mathrm{C}$ intake and that high doses of vitamin $\mathrm{C}$ may significantly reduce indinavir plasma concentrations. Other studies $[42,33,113]$ have shown that adverse events of other antiretrovirals, such as zidovudine's effects on leukopenia, may be prevented by vitamin $\mathrm{C}$ supplementation in animal models. Studies by Shor-Posner et al. [114] also alludes that impaired neuro-protection resulting from oxidative stress has been implicated in neuro-degeneration in a number of pathologic conditions of the brain, including both subcortical and cortical type dementias and it is demonstrated that preventive actions with antioxidant treatment in an animal model of AIDS dementia [115] has been successful.

Under normal conditions, numerous cellular antioxidant systems exist to defend against oxidant stress and maintain the redox balance of the cell. In the extracellular spaces, the sulphydryls group of plasma proteins, including plasma albumin serve as antioxidants [116]. ROS have useful functions such as combating microorganisms by phagocytes and serving as mediators for signal transduction and gene expression, but they can also cause damage through oxidation and peroxidation of DNA, proteins and lipids [90]. Certain foods are good sources of antioxidants, hence the importance of their inclusion in the treatment of illnesses accompanied by oxidative stress-mediated injuries.

\section{Antioxidants/antioxidant enzymes in the pathogenesis of HAART toxicities}

Biological systems provide favourable conditions for controlled oxidative reactions because of the existence of unsaturated fats in cell membranes and the abundance of oxidative reactions in normal metabolism. The susceptibility of a given tissue/cell to OS would therefore depend on a number of factors including nutrient antioxidants, enzymatic and non-enzymatic scavengers and factors related to inactivation of oxidation by-products [117]. In the case of HIV/AIDS, although the global prevalence of AIDS has recently stabilized, there still exist regional differences in trends and modes of transmission. To halt the progression of the disease severe symptoms, researchers are working on all possible therapeutic gap offered by the virus to potentially stem the scourge of the disease [52]. Several studies $[118,119]$ have reported that levels of ROS within semen can be reduced by augmenting the scavenging capacity of seminal plasma using oral antioxidant supplements. While these studies may show improvements in sperm quality with antioxidant treatment, the ability of these changes to translate into improved chances of pregnancy is less clear nor are the complex interactions in disease states like HIV with its treatment clearly known. More so, although much literature has been devoted to drug effects on spermatozoal morphology and physiology, data on the distribution of drugs into the seminal compartment remain scanty [46] with diverse opinions on compartmentalization [17]. One of the key focuses of HIV-1 is the depletion of CD4+ T cells (helper $\mathrm{T}$ lymphocytes) which provide receptor sites for HIV binding, thereby creating high viral turnover with enhancement of pathogenicity of the virus [120] and subsequent manifestation of AIDS. However, with the discovery of the role of ROS in the development of AIDS, there is broadening of search for mitigating agents towards amelioration of the FR-mediated perturbations.

Preventative antioxidants, such as metal chelators and metal binding proteins, block the formation of new ROS, whereas scavenger antioxidants, such as vitamins $\mathrm{E}$ and $\mathrm{C}$, beta-carotene and other antioxidant dietary supplements, glutathione and enzymes, remove ROS already generated by cellular oxidation (see table 2 for summary). Dietary products such as lycopene (tomato products), vitamin C (citrus fruits and green vegetables) and vitamin E (vegetable oils, nuts and seeds) are some of the excellent sources of antioxidants [14] (Table 3). Vitamins are a class of nutrients that are essentially required by the 
Citation: Azu OO (2012) The Male Genital Tract in the Era of Highly Active Antiretroviral Therapy (HAART): Implication for Antioxidant Therapy. J AIDS Clinic Res 3:169. doi:10.4172/2155-6113.1000169

Page 7 of 16

\begin{tabular}{|c|c|c|c|c|c|}
\hline Antioxidant modalities & Nature of experiment & Subjects & Outcome & Duration & References \\
\hline $\begin{array}{l}\text { Serum levels of } \\
\text { vitamins } A \text { and } E\end{array}$ & $\begin{array}{l}\text { Non-concurrent prospective study } \\
\text { in } 341 \text { men. }\end{array}$ & vitamin E levels $(23.5 \mu \mathrm{mol} / \mathrm{l})$ & Decrease in risk of progression to AIDS & - & Tang et al. [156] \\
\hline $\begin{array}{l}\text { Antioxidant } \\
\text { vitamins }(A, C, E) \\
\text { supplementation }\end{array}$ & $\begin{array}{l}\text { Measurement of levels of } \\
\text { oxidatively-modified DNA bases } \\
\text { in lymphocytes of sero-positive } \\
\text { patients \& controls. }\end{array}$ & $\begin{array}{l}\text { Asymptomatic HIV-infected } \\
\text { patients ( } n \text { is } 30) \text {, as well as } \\
\text { in control groups ( } 10 \text { healthy } \\
\text { volunteers and } 15 \text { HIV-sero- } \\
\text { negative injected drug users). }\end{array}$ & $\begin{array}{l}\text { Significant decrease in the levels of } \\
\text { all modified DNA bases; decreased } \\
\text { antioxidant enzyme activities }\end{array}$ & 6 months. & Jaruga et al. [53] \\
\hline $\begin{array}{l}\text { Daily supplements } \\
\text { of vitamin } A \text {, } \\
\text { multivitamins } \\
\text { (vitamins } B, C \text {, and E). }\end{array}$ & $\begin{array}{l}1078 \text { pregnant women infected } \\
\text { with HIV in a double-blind, } \\
\text { placebo-controlled trial. }\end{array}$ & Human & $\begin{array}{l}\text { Significantly higher CD4+ and CD8+ } \\
\text { cell counts and significantly lower viral } \\
\text { loads. Multivitamin supplements delay } \\
\text { the progression of HIV disease and } \\
\text { provide an effective }\end{array}$ & $\begin{array}{l}\text { Over a two-year } \\
\text { period }\end{array}$ & Fawzi et al. [208] \\
\hline Selenium therapy trial & $\begin{array}{l}\text { Two hundred and fifty-nine HIV- } \\
\text { infected participants were enrolled } \\
\text { in a randomized double blind trial. }\end{array}$ & Human & Lower risk of hospitalization & 1998 to 2000. & Burbano et al. [114] \\
\hline $\begin{array}{l}\text { Endogenous Vitamin } \\
\text { C }\end{array}$ & 85 HIV positive patients & Human & $\begin{array}{l}\text { No difference were found in the level } \\
\text { of vitamin C }\end{array}$ & 3 to 6 months. & Ngondi et al. [30] \\
\hline Vitamins $\mathrm{E}$ and $\mathrm{C}$ & $\begin{array}{l}50 \mathrm{mg} / \mathrm{kg} \text { diet } \text { a-tocopheryl } \\
\text { acetate, Vitamin E }(200 \mathrm{mg} \cdot \mathrm{kg}-1 \\
\text { diet, }\end{array}$ & Fifty male rabbits. & $\begin{array}{l}\text { Increase in TBA-RS } \\
\text { association with supranutritional levels } \\
\text { of vitamins } E \text { and } C \text { inhibited the } \\
\text { oxidative processes and improved } \\
\text { the characteristics of fresh and stored } \\
\text { rabbit semen }\end{array}$ & $\begin{array}{l}\text { For } 5 \text { wks } \\
\text { starting from the } \\
5^{\text {th }} \text { month of age }\end{array}$ & Castellini et al. [139] \\
\hline $\begin{array}{l}\text { Zidovudine (AZT) and } \\
\text { vitamin C }\end{array}$ & $\begin{array}{l}\text { AZT }(1 \mathrm{mg} / \mathrm{ml}) \text { in the drinking } \\
\text { water, six vitamin } C(10 \mathrm{~g} / \mathrm{kg} \text { of } \\
\text { food) and } A Z T \text {, six vitamin } C \text { alone }\end{array}$ & Animal (rat) & $\begin{array}{l}\text { AZT caused morphological alterations in } \\
\text { cardiac myocyte mitochondria, prevented } \\
\text { by vitamin C; Vitamin C antagonizes } \\
\text { these adverse effects of AZT }\end{array}$ & $\begin{array}{l}\mathrm{L} \text { o } \mathrm{n} \mathrm{g}-\mathrm{t} \text { e } \mathrm{r} \mathrm{m} \\
\text { treatment for } 8 \\
\text { months }\end{array}$ & $\begin{array}{l}\text { Papparella et al. } \\
\text { [113] }\end{array}$ \\
\hline
\end{tabular}

Table 2: Summary of antioxidant modalities and oxidative outcomes.

\begin{tabular}{|c|c|c|c|c|}
\hline AOIAOE & Location/activity & Discovery & Key function(s) & References \\
\hline SOD & Epididymis & 1968 & important enzyme & Fridovich [209]; \\
\hline GPX & Tissues & 1957 & $\begin{array}{l}\text { Destroys } \mathrm{H}_{2} \mathrm{O}_{2} \text { and organic hydroperoxides by } \\
\text { catalysing reduction of hydroperoxides. }\end{array}$ & Mills [210]. \\
\hline CAT & Peroxisomes & 1900 & Antioxidant enzyme against hydrogen peroxide & Loew [211]; Fujii et al. [190]; \\
\hline Vitamin C & $\begin{array}{l}\text { Mammalian tissues and } \\
\text { plasma. Water soluble. }\end{array}$ & Isolated in 1928 & Body metabolism, antioxidant electron donor & $\begin{array}{l}\text { Burns [212]; Cheeseman et al. [213]; } \\
\text { Bendich [138] }\end{array}$ \\
\hline Vitamin E & $\begin{array}{l}\text { Mammalian tissues and } \\
\text { plasma. Lipid-soluble }\end{array}$ & 75 years ago & Chain-breaking antioxidant; & $\begin{array}{l}\text { Evans and Bishop [122]; Burton et al. [123]; } \\
\text { Ingold et al. [124]; Cheeseman et al. [213] }\end{array}$ \\
\hline $\begin{array}{l}\text { Carotenoids (e.g. } \\
\beta \text {-carotene) }\end{array}$ & Pro-vitamin A & 1929 & Singlet oxygen quenchers and as antioxidants & Olson [214] \\
\hline Selenium & $\begin{array}{l}\text { In vivo micronutrient } \\
\text { required for GPx }\end{array}$ & $\begin{array}{c}\text { first confirmed in } 1933, \\
\text { identified in lab animals, } 1957\end{array}$ & Antioxidant, required for proper functioning of GPx. & $\begin{array}{l}\text { Spallholz [215]; Shor-Posner et al. } \\
\text { [179]. }\end{array}$ \\
\hline Vitamin A & Plasma & 1913 & Immune function & Olson [214] \\
\hline Lycopene & Body tissues, testis & & potent antioxidant & \\
\hline $\begin{array}{l}\mathrm{N} \text {-acetylcysteine } \\
\text { (NAC) }\end{array}$ & In vivo in plasma & $\begin{array}{l}\text { some } \\
50 \text { years ago }\end{array}$ & $\begin{array}{l}\text { Its effect is based on breaking of the disulphide } \\
\text { bridges of the high-molecular-weight glycoproteins } \\
\text { of the mucus, resulting in reduced viscosity. } \\
\text { Replenishes intracellular GSH levels }\end{array}$ & Aitio [90]; Atkuri et al. [164]. \\
\hline
\end{tabular}

Key: SOD is Superoxide dismutase: GPx is Glutathione peroxidase: CAT is Catalase; AO/AOE is antioxidant/antioxidant enzyme

Table 3: Summary of antioxidants and key function(s).

body for its various biochemical and physiological processes. Mostly, the human body does not synthesize them; therefore, they must be supplied by the diet in the required amount [121]. For the purposes of this review, only vitamins $\mathrm{C}, \mathrm{E}, \mathrm{A}$ and lycopene would be discussed in detailed.

Therapeutic approaches with antioxidants in HIV/AIDS treatment presents a challenge to researchers because AIDS itself is a vexing disease with many implications. Therefore, the understanding of the mechanistic information regarding the interactions of the various modalities of biological and exogenous antioxidants in the course of therapy would significantly broaden the scope of treatment with consequent reduction of the morbidity and mortality associated with HIV/AIDS.

Vitamin E: Vitamin E, the generic term for a group of eight lipid-soluble substances, four tocopherols and four tocotrienols, was discovered by Evans \& Bishop [122] during a course of studies examining the relationship between fertility and nutrition [35] Vitamin E, potent peroxyl radical scavenger is a chain-breaking antioxidant that prevents the propagation of free radical damage in biological membranes $[123,124]$. The critical role played by vitamin $\mathrm{E}$ in testicular protection was highlighted in the work of [125] where testicular degeneration was observed in vitamin E-deficient male rats. This may have resulted from inadequate protection against free radicals generated unavoidably during cytochrome P-450-catalysed synthesis of testosterone in Leydig cells. If this proves to be correct, then an important function of vitamin $\mathrm{E}$ in the testis is to protect tissues against the harmful effects of free radicals generated during a normal metabolic process, i.e. the synthesis of a steroid hormone. Low serum vitamin $\mathrm{E}$ 
levels in HIV-1-infected individuals have been correlated with a higher degree of lipid peroxidation [126]

The antioxidant potency of vitamin E may be enhanced by its recycling due to the reduction of its phenoxyl radicals. Ascorbic acid has been shown to reduce vitamin E phenoxyl radical back to the phenolic form, in other words, to recycle vitamin E in model systems as well as in membranes and lipoproteins [127]. During this interaction, ascorbic acid is oxidized to semidehydroascorbyl radical which can be effectively reduced by dihydrolipoic acid (but not glutathione) thereby contributing in the recycling of vitamin E [116]. Interestingly, thiols are not able to interact with directly with vitamin $\mathrm{E}$ phenoxyl radical. Paradoxically, hindered phenolic compounds can contribute to both prevention of oxidative injury and oxidative injury. In this case, vitamin $\mathrm{E}$ is an efficient antioxidant not only due to its high reactivity towards oxidizing radicals but also because of the low reactivity of its phenoxyl radicals towards critical biomolecules [116].

The association of vitamin E deficiencies and OS with HIV infected patients has been reported by Pacht et al. [128]. In a study involving 296 HIV seropositive male patients, Abrams et al. [129] showed that by doubling the vitamin $\mathrm{E}$ intake of the patients, the risk of progression to AIDS declined. Also, Geissler et al. [130] suggests in their study that combination of vitamin $\mathrm{E}$ and AZT may be beneficial in reducing viral load as well as suppressing bone marrow toxicity. AKR/J mice treated with $\mathrm{d} 4 \mathrm{~T}$ showed significant alterations in the OS genes compared to controls and the effects were reversed by ascorbate and tocopherol treatment [131]. Another mechanism by which vitamin E enhances immune functions is through its antioxidant properties by preventing the peroxidation of rapidly proliferating cells of the immune system [132]. Thus, in addition to its role as a free-radical scavenger, the impact of vitamin $\mathrm{E}$ on the regulation of various cytokines in the immune process is believed to play a major role in inhibiting HIV-1 replication.

One signal transduction pathway in which vitamin $\mathrm{E}$ exerts an effect that may depend on its antioxidant function is in the nuclear factor KB (NF-kB) pathway [133] found that NF-kB levels in HIV1 infected lymphocyte cell cultures were lower with subsequent reduction in viral replication and inhibition of cell death. NF-kB is activated by oxidative stressors such as hydrogen peroxide and lipid hydroperoxides, hence provides the plausible intervention of vitamin $\mathrm{E}$ in preventing NF-kB activation [134]. However, they appear to be discrepancies in the outcomes from the use of different redox forms of vitamin $\mathrm{E}$; while some authorities have stated that vitamin $\mathrm{E}$ acetate blocks NF-kB activation in HIV-1-infected cell cultures [135], others report that the effects were minimal with vitamin E [136]. This calls for additional studies on the different forms of vitamin $\mathrm{E}$ especially in HIV therapeutic protocols to unravel this discordancy. Nonetheless, it has been shown that in vivo supplementation with vitamin E significantly decreases monocyte superoxide anion release, lipid peroxidation as well as interleukin-1 $\beta$ (IL-1 $\beta$ ) release mediated via inhibition of protein kinase by vitamin $\mathrm{E}$ [137].

Vitamin C: Vitamin C, also called ascorbic acid, is a water-soluble antioxidant that is required for normal body metabolism and physiology. Vitamin C's primary role is to neutralize free radicals and this is achieved because it is an excellent source of electrons therefore it "can donate electrons to free radicals such as hydroxyl and superoxide radicals and quench their reactivity" [138]. The role of vitamin C has become relevant in many intervention studies relying on antioxidant modalities because peroxidative damage has been proposed as one major cause of defective sperm functioning and many authors agree that loss of sperm motility is often related to the accumulation of ROS [139].
Literature on the role of vitamin $C$ in antiretroviral therapeutic management has not been conclusive due to conflicting views as to the actual beneficial (or otherwise) effects of its use in HAART protocols. While Stephensen et al. [140] shows that vitamin C requirements may be higher in those with HIV infection compared to sero-negative individuals (which supports decreased plasma ascorbate concentrations in HIV patients), Slain et al. and Lee et al. [111,112] states that limited studies have found a reduction in antiretroviral concentrations with vitamin $C$ intake and that high doses of vitamin $C$ may significantly reduce indinavir plasma concentrations. Garcia-de-la-Asuncion et al. [33] and Papparella et al. [113] however, have shown that adverse events of zidovudine's effects on leukopenia may be prevented by vitamin $\mathrm{C}$ supplementation in animal models. In view of these divergent views, we argue that increase in OS brought about by HIV infection and/or HAART will tilt towards an unfavourable decline in defense system with consequent damage to cellular organelles and enzymes.

Vitamin C protects sperm from oxidative damage [141] and has been reported to improve sperm quality in smokers [142]. As an antioxidant, vitamin $\mathrm{C}$ can rejuvenate vitamin $\mathrm{E}$, making it an indirect contributor to the fight against free radical damage in the lipids. It's not surprising, then, that these two vitamins can be effective partners in reducing the destructive process of lipid peroxidation. This synergistic combination of vitamins $\mathrm{C}$ and $\mathrm{E}$ has been researched in human and animal studies of diabetes and cerebral arteriosclerosis [143]. The synergistic combination of vitamin $\mathrm{C}$ and vitamin $\mathrm{E}$ may be further enhanced by the addition of vitamin A.

Low plasma ascorbate levels have been reported in a study of 228 PLWHA in Ghana by Obirikorang et al. [144] which, in agreement with data from other researchers buttresses that high viraemic load due to HIV infection depletes this antioxidant hence need for supplementation to accentuate the decline. Jaruga et al. [53] investigated the role of supplementation with antioxidant vitamins A, $\mathrm{C}$ and $\mathrm{E}$ on HIV seropositive asymptomatic patients as well as using lymphocyte DNA samples. The outcome was a significant decrease in all modified DNA bases when compared with controls suggestive of a beneficial role for HIV infected patients. Although vitamins C, E, and $A$ are effective antioxidants in vitro, there are only a limited number of studies in humans that have addressed the efficacy of these compounds as antioxidants in vivo as there exist complexities in interactions with other chemicals in the milieu. Using single gel electrophoresis (comet assay), Duthie et al. [145] observed that supplementation of healthy volunteers with vitamin $\mathrm{C}(100 \mathrm{mg} / \mathrm{d})$, vitamin $\mathrm{E}(280 \mathrm{mg} / \mathrm{d})$, and $\beta$-carotene $(25 \mathrm{mg} / \mathrm{d})$ significantly reduced base damage in lymphocyte DNA. Although the comet assay allowed to detect overall base damage, it is impossible to describe the effect of the supplementation on a particular base product. This is an important issue since Podmore at al. [146] reported that supplementation of volunteers with vitamin C may cause an increase in the level of one base product (8-OH-Ade) and reduce the level of another $(8-\mathrm{OH}-\mathrm{Gua})$ at the same time. It is possible that vitamin $\mathrm{C}$ positively influences the removal of 8 -OHGua from the DNA by most likely up-regulating the activity of the repair enzymes [147]. Mutagenicity has been implicated with modified bases [78] and their increased production in lymphocytes of HIV-infected patients may be related to malignancies associated with AIDS. OS-mediated apoptosis is speculated to be the direct cause of lymphocyte loss in patients infected with HIV $[84,91]$ but the mechanisms that directly trigger the apoptosis remains elusive.

Vitamin A: There is ample evidence from both human and animal studies that supplementation with vitamins $\mathrm{A}$ and/or $\mathrm{E}$ 
enhances immunity and resistance to various infectious diseases $[132,148]$. Previous studies have found significant proportions of HIV-1-seropositive individuals with low serum levels of either or both vitamins $[149,150]$ and low serum levels or low intakes of vitamin A in HIV-1 infection have been associated with lower CD4+ cell counts [149]. HIV infection is documented to affect the digestive system which in turn affects the absorption and metabolism of this vitamin [151]. This continued exacerbation of the depletion is further encouraged by decreased dietary intake [152], high urinary losses, impaired hepatic protein synthesis [153], and increased nutritional demands due to chronic infection. Most, if not all of these factors would also affect vitamin A supplementation. Some studies have shown that even after supplementation, no significant changes are seen in the plasma levels of vitamin $\mathrm{A}$ and it is possible that this is due to malabsorption owing to AIDS-related mucosal damage [154]. In animal models, vitamin A deficiency has been associated with diminished resistance to infections and induces OS [155]. Since plasma vitamin A levels are homeostatically controlled and do not tend to fluctuate with dietary intake, there is little association between serum vitamin A levels and vitamin A intake from food and/or supplements in subjects. However, in a previous study of dietary intake by Tang et al. [156], it was found that high vitamin A intakes were not associated with a decreased risk of progression to AIDS, whereas moderate intakes were associated with an approximate $40 \%$ decrease in risk of AIDS progression.

Observational studies of HIV-infected pregnant women showed low levels of vitamin A with an increased risk of mother-to-child transmission (MTCT), but the impact of antenatal supplementation remains doubtful [52]. Carotenoids (provitamin A carotenoids) can be converted to vitamin A. As well as the ability to quench excited states, carotenoids can also react with free radicals [157]. However, unlike the quenching of singlet oxygen which mainly leads to energy dissipation as heat, the reactions of a carotenoid (or any antioxidant) with a free radical will lead to electron transfer or possibly addition reactions. The major fact to note is that the "odd" electron which characterizes a free radical is not lost.

Thus for a free radical (R') reacting with a carotenoid (CAR), reactions such as:

$$
\begin{aligned}
& \mathrm{R} ”+\mathrm{CAR}(\mathrm{H}) \leftrightarrow \mathrm{RH}+\mathrm{CAR} \text { " and } \\
& \mathrm{R}+\mathrm{CAR} \sim \mathrm{R}-+\mathrm{CAR}^{\prime *}
\end{aligned}
$$

are expected, depending on the redox potentials of the species involved. It is also suggested that $\beta$-carotene might act as a pro-oxidant at high oxygen pressures [158] and clinical studies have buttressed this [52]. It is suggested that carotenoid cleavage products formed during oxidative attack are responsible for alteration of antioxidative action [159]. Therefore, further investigations as to the mechanics and kinetics of vitamin A-carotenoid deprivation in HIV therapy will continue to attract focus bearing in mind that they are necessary in immune response of macrophages at the onset of HIV infection.

$\mathrm{N}$-acetylcysteine (NAC): NAC was introduced as a mucolytic agent more than 50 years ago [90] and has radicalized intervention protocols for many chronic diseases like COPD and HIV/AIDS through its central role in antioxidant defense against ROS $[90,160]$. Although the commonly used antioxidants like vitamins $\mathrm{C}$ and $\mathrm{E}$ can directly neutralize free radicals, they cannot, however, replenish the cysteine required for GSH synthesis and replenishment [161]. Thus, not surprisingly, the cysteine pro-drug NAC, which supplies the cysteine necessary for GSH synthesis, has proven to be more effective in treating disease-associated oxidative stress. Although NAC (and
GSH) can directly scavenge free radicals, the rate constants for their reaction with ROS are several orders of magnitude lower than those of antioxidant enzymes such as superoxide dismutase (SOD), catalase and glutathione peroxidase [162]. Thus, the direct free radical scavenging activity of NAC is not likely to be of great importance for its antioxidant activity in vivo. Several placebo-controlled trials with GSH-deficient HIV-infected subjects have demonstrated that orally administered NAC replenishes erythrocyte and lymphocyte GSH and improves T cell function [163]. Ledru et al. [164] earlier demonstrated that PIinduced HAART-associated lipodystrophy was due to dysregulation of TNF- $\alpha$, a major source of ROS [165] and this was successfully blocked by treatment with NAC.

As HIV infection prevails among persons of reproductive age, infertility is also a growing concern in the era of HAART [47]. The increased incidence of this condition, which has been credited to the chronic use of anti-retrovirals, leads to concerns about the longterm adverse effects of HAART as well as need for a suitable enduring treatment for an aging patient population. Micronutrient supplements have been proposed as low-cost immunomodulating interventions that may slow the progression of HIV disease and if efficacious, could delay the onset of advanced disease and the need for antiretroviral therapy, saving antiretroviral drugs for when they may be most needed and reducing drug-related adverse events and costs $[166,167]$.

Lycopene: Lycopene have been found to be the best scavenger of free radicals. Deficiencies of $\beta$-carotene, lycopene, retinol, vitamin $\mathrm{E}$, and glutathione have been reported and often relate to HIV disease status [168]. Low blood concentrations of zinc, copper, and vitamins A, E, and B6 were found in a significant number of South African HIV-infected children [169]. Most studies are cross-sectional and do not indicate the causality between HIV disease status and micronutrient deficiencies. Observational studies on micronutrient are limited by the challenge of separating the effects of the acute-phase response (depresses serum micronutrient concentrations) from true nutritional deficiencies [170].

Selenium: The impact of micronutrient supplementation in HIV infection is a subject that has continued to attract intense research. The trace element selenium (Se) has been potentially utilized for the nutritional chemoprevention study because of its impact on HIV disease progression [171,107] as well as its important function in antioxidant defense.

Selenium has been reported to alter cellular response (i.e., phagocytosis), and microorganism pathogenicity $[172,173]$ as well as the production of individual cytokines that have a crucial function in host defense $[174,175]$. Moreover, there is evidence that levels of selenium and glutathione peroxidase have been reported to decrease with age and as HIV disease progresses [176] which supports the resulting elevation in oxidative stress, declining immune system and greater risk of infections in older patients.

There is a dual role of zinc in HIV infection: Zinc has a fundamental impact in sustaining cellular immunity, but it is also necessary for HIV assembly and infectivity [170]. Selenium reduced the virulence of HIV and slowed disease progression. On the other hand, low-dose supplementation of trace elements (selenium and zinc) has been reported to provide significant improvement in immune response and less infectious events in elderly patients $[177,178]$. Therefore, it would be informed to suggest that selenium supplementation which may be an affordable and a potentially useful therapy would reduce the OS-related activities of HAART especially in resource-deprived communities [179]. 
Selenium deficiency may result in decreased activity of glutathione peroxidase (GPX), a major antioxidant system which reduces the levels of free radicals able to stimulate HIV replication and CD4-lymphocyte cell apoptosis. Thus, as Se concentration decreases, it should give rise to an increase in oxidative stress, HIV replication, and accelerated CD4- lymphocyte cell death [180]. Reduced GPX activity and reduced glutathione $(\mathrm{GSH})$ values increase after Se supplementation. Because GPX and GSH play an important role in the natural enzymatic defense system by detoxifying hydrogen peroxide into water, Se supplementation could be of great interest in protecting cells against oxidative stress. In patients infected with RNA viruses, Se supplementation inhibits reverse transcriptase activity. Therefore, Se supplementation in HIVinfected individuals could also halt the replication of the retrovirus and retard the development of AIDS in early stages of the disease [181]. The testes contain high levels of Se concentrations but despite this, Se supplementation data remain conflictive with increased [182], unchanged [183] and even decreased [184] in sperm motility indices reported by researchers.

Antioxidant enzymes: Although many enzymes can function as antioxidants [185], other non-enzymatic antioxidants also present in semen (vitamin C, vitamin E, glutathione, amino acids, carotenoids, prostasomes) directly neutralize FR activity. In addition, they also provide protection against FR attack by two other mechanisms; albumin can intercept free radicals by becoming oxidized itself, thereby sparing sperm from attack [186]. Alternatively, extracellular organelles (prostasomes) secreted by the prostate have been shown to fuse with leukocytes within semen and reduce their production of free radicals [187]. Antioxidants contained within seminal plasma are obviously helpful for preventing sperm oxidative attack following ejaculation. However, during spermatogenesis and epididymal storage, the sperm are not in contact with seminal plasma antioxidants and must rely on epididymal/testicular antioxidants and their own intrinsic antioxidant capacity for protection. Sperm are therefore vulnerable to oxidative damage during epididymal transit, especially when there is epididymal inflammation such as male genital tract infection [188]. In addition, results have demonstrated a statistically significant reduction in the percentage of progressively motile spermatozoa in patients with HIV-1 infection during treatment with antiretroviral therapy [18]. Therefore, while seminal plasma antioxidants may help minimize ejaculated sperm oxidative stress, they have no capacity to prevent oxidative damage initiated 'upstream' at the level of the testis and epididymis.

However, it must be stressed that low level production of free radicals by sperm plays a positive role in preparation for fertilization (capacitation). Hydrogen peroxide stimulates the acrosome reaction and sperm hyperactivation [4], thereby assisting the sperm's transit through the cumulus and zona pellucida.

Glutathione peroxidase (GPx): A variety of enzymatic (superoxide dismutase, catalase, glutathione peroxidase) antioxidants present in human serum become relevant to circumvent HIV-1 replication secondary to cellular ROS production by a pro-oxidant effect of inflammatory cytokines and/or a polymorphonuclear leukocyte activation [189]. Glutathione is a tripeptidyl molecule and present in either the reduced (GSH) or the oxidized state (GSSG) by forming a disulfide bond between two molecules. Since it contains a reactive sulfhydryl group, GSH participates in preserving the intracellular milieu in a reduced state in addition to electron donation to GPX [190]. It maintains cellular redox status via a mechanism that scavenges FRs and hydrogen peroxide as well as neutralizing toxic metabolites by condensing with them both enzymatically and non-enzymatically
[191]. Dose-dependent declines in GSH levels have been reported by [68] following treatment with AZT + IDV suggestive that the metabolic capability of the glutathione system has been exceeded.

Several investigators have implicated depletion of glutathione (GSH) and production of reactive oxygen intermediates in the regulation of the human immunodeficiency virus (HIV) [195]. Additional studies indicate that enzymes involved in antioxidant defense are altered in HIV/AIDS. Specifically, levels of Se and GPx decrease as HIV disease progresses [193]. It is also shown that HIV-infected individuals have decreased intracellular glutathione (GSH) levels in their circulating $\mathrm{T}$ cells. Since GSH is the major protection against the production of ROS, it is hypothesized that the observed decrease is due to a chronic oxidative stress induced by continual exposure to elevated levels of inflammatory cytokines. Together, these results provide a rationale for clinical trials testing the efficacy of GSH-replenishing drugs such as NAC in the treatment of AIDS [192].

GPx plays an important role as defense mechanism in mammals, against oxidative damage by catalyzing the reduction of a variety of hydroperoxides, using glutathione as the reducing substrate. In addition to its role as a substrate in GSH redox cycle, glutathione, also act as a direct endogenous scavenger of hydroxyl radicals. HAART may reduce glutathione (GSH) synthesis, enhance GSH utilization, or limit intracellular reduction of its oxidized form (GSSG) consequent upon OS-mediated processes [68]. As a consequence of GSH deficiency, a number of related functions may be impaired such as a decrease in reducing capacity and accumulations of lipid peroxidation products. The later have been demonstrated to result in impairment of spermatogenic morphology and functions.

OS during HIV infection has been linked to changes in plasma and/or cellular markers such as glutathione and selenium [194]. Under this condition, GSH is consumed by GSH-related enzymes to detoxify peroxides produced by increased lipid peroxidation, which is caused by chemical assaults $[195,196]$. This suggests that enhanced oxidative stress and disturbed glutathione metabolism occur after initiating HAART. These effects appear to be related to persistent TNF- $\alpha$ activation in HIV-infected patients as has been described in Muller et al. [110]. Furthermore, significant decline in glutathione reductase (GR) levels have been documented in HAART patients. It is cognizant that lower GR levels and oxidative stress in general are known to upregulate inflammatory cytokine activities in patients receiving HAART [196]. HIV-infected individuals can have significantly higher GPx activity than HIV-uninfected individuals [189]. Since glutathione administration improves male infertility, compounds that increase GSH levels may be used in the treatment of male infertility [197] and may be helpful in attenuating the disturbances of HAART in patients desiring sustenance of reproductive viability.

In a prospective study of $35 \mathrm{HIV}$-infected participants and $20 \mathrm{HIV}$ negative controls, Sundaram et al. [196] documents alterations in the levels of GPx, albumin, GR and uric acid among HAART-experienced participants. The study suggests that enhanced OS and disturbed glutathione metabolism occur after initiating HAART which appear to be related to persistent tumor necrosis factor-a (TNF-a) activation in HIV-infected patients. Nonetheless, studies from the developed world have documented biochemical changes that could be a result of greater utilization of antioxidant micronutrients subsequent to increased OS rather than inadequate dietary intake [198] or malabsorption [154].

Superoxide Dismutase (SOD): The superoxide anion is produced by a one-electron reduction of an oxygen molecule and initiates a 
radical chain reaction. SOD dismutates superoxide anion to hydrogen peroxide (a potential testicular toxicant) and plays a central part in antioxidative reactions [190]. A pivotal role of SOD in protection of testicular cells against heat stress-induced apoptosis has been demonstrated in vivo and in vitro [199]. NNRTIs like nevirapine is known to cause severe depletion of tissue glutathione and loss of activities of antioxidant enzymes, especially SOD and CAT in treated rats. The observed decrease in SOD activity suggests inactivation (or overutilization) of the enzyme probably caused by increased superoxide radical production, or an inhibition by the hydrogen peroxide as a result of corresponding decrease in the activity of CAT in nevirapine metabolism [200]. Testicular lipid peroxidation process induced by nevirapine may destroy the structure of lipid matrix in membranes of spermatozoa and may lead to rapid loss of intracellular ATP resulting to axonemal damage, decreased sperm viability and increased mid-piece morphological defects, and even inhibits spermatogenesis in extreme cases [201].

Catalase (CAT): Catalase exclusively detoxifies hydrogen peroxide and has no electron donor requirement. Although CAT is a well-known antioxidative enzyme and has been implicated in protection against hydrogen peroxide, its localization is limited to the peroxisome. It plays a role in organs such as liver, but its specific function in male genital tract is unknown [190]. Spermatozoa have been demonstrated to have the ability to generate ROS as early as in 1943 [202]. However, it is only recently that cellular redox activity is found to be important for sperm to attain a functionally competent state to fertilize an oocyte [4]. The microenvironment in the MGT has to provide enzymatic and nonenzymatic strategies to protect the spermatozoa from excessive OS and so to preserve sperm function and their DNA integrity [201]. This is even more significant because in the post-ejaculatory phase and in the female genital tract, spermatozoa have to depend on antioxidants, metal ions and proteins provisions in male accessory sex gland secretions for protection [3].

Antioxidant enzyme levels are sensitive to oxidative stress and alterations have been observed in various studies which prove that cell damage and weakened antioxidant defense is common in HIVinfected individuals [196] as well as in combination antiretroviral therapy (cART). In the MGT, varying amounts of antioxidant enzymes superoxide dismutase (SOD), catalase (CAT) and glutathione peroxidase (GPx) are detected in secretions of individual accessory sex gland, with SOD demonstrating the highest level of activity [203]. Reduction in activity of CAT has been reported by [200] and may reflect an inability of tissues to eliminate the hydrogen peroxide produced following treatment with NNRTI-nevirapine. It may also be due to overutilization of the enzyme caused by excess reactive oxygen species.

\section{Future Perspectives}

As humans infected with HIV have been shown to be under oxidative stress, perturbations of the antioxidant defense system in HIV-infected humans (include changes in ascorbic acid, $\alpha$-tocopherol, carotenoids, selenium, superoxide dismutase and glutathione [115] will continue to attract rigorous attention from scientist in the years to come. In 2008 alone, the majority of the 33 million HIV-infected people worldwide were in their reproductive years and the HIV seropositive male partner of a growing number of sero-discordant couples is seeking assisted reproductive techniques to have children without contaminating the partner and embryo [44]. In the light of the information regarding the effects of various HAART modalities on various systems of the body especially the MGT and the need to identify better therapeutic protocols for the HIV/AIDS pandemic, it is envisaged that with the newer HAART drugs undergoing advanced stage of clinical trials, these myriad of issues may become resolved. Indeed, various studies have demonstrated a relationship between mitochondria and sperm motility [104] and since several antiretroviral drugs have mitochondrial toxicity, it becomes highly interesting how scientists unravel this connection between the 'power-house' and HAART in the years ahead, specifically to reduce the deleterious consequences of the latter on the former.

\section{Conclusion}

Current drug therapies against HIV/AIDS and other therapeutic measures such as administration of $\mathrm{N}$-acetylcysteine supplements, may improve the quality of patient care but the occurrence of HAARTrelated OS would continue to draw fervent research in the near future.

\section{References}

1. Sharpe RM (1986) Paracrine control of the testis. Clin Endocrinol Metab 15 185-207.

2. Snow-Lisy DC, Samlaski MK, Labhasetwar V Sabanegh Jr ES (2011) Drug delivery to the testis: current status and potential pathways for the development of novel therapeutics. Drug Deliv and Transl Res 1: 351-360.

3. O WS, Chen H, Chow PH (2006) Male genital tract antioxidant enzymes--their ability to preserve sperm DNA integrity. Mol Cell Endocrinol 250: 80-83.

4. de Lamirande E, Gagnon C (1995) Capacitation-associated production of superoxide anion by human spermatozoa. Free Radic Biol Med 18: 487-495

5. Inskeep PB, Magargee SF, Hammerstedt RH (1985) Alterations in motility and metabolism associated with sperm interaction with accessory sex gland fluids. Arch Biochem Biophys 241: 1-9.

6. Carpino A, Sisci D, Aquila S, Salerno M, Siciliano L (1994) Adnexal gland secretion markers in unexplained asthenozoospermia. Arch Androl 32: 37-43.

7. Topper EK, Killian GJ, Way A, Engel B, Woelders H (1999) Influence of capacitation and fluids from the male and female genital tract on the zona binding ability of bull spermatozoa. J Reprod Fertil 115: 175-183.

8. Pace GW, Leaf CD (1995) The role of oxidative stress in HIV disease. Free Radic Biol Med 19: 523-528.

9. Tang AM, Smit E, Semba RD, Shah N, Lyles CM (2000) Improved antioxidant status among HIV-infected injecting drug users on potent antiretroviral therapy. J Acquir Immune Defic Syndr 23: 321-326.

10. Hagmann M (2003) Study confirms effectiveness of antiretroviral drugs for HIV patients. Bull World Health Organ. 81: 918-919.

11. Halliwell B (1987) Oxidants and human disease: some new concepts. FASEB 1: $358-364$.

12. Jaeschke $H$ (1995) Mechanisms of Oxidant Stress-Induced Acute Tissue Injury Proc Soc Exp Biol Med 209: 104-111.

13. Favier A, Sappey C, Leclerc P, Faure P, Micoud M (1994) Antioxidant status and lipid peroxidation in patients infected with HIV. Chem Biol Interact 91: 165-180.

14. Agarwal A, Prabakaran SA and Sikka SC (2007) Clinical relevance of oxidative stress in patients with male factor infertility: Evidence-Based Analysis 26: 1-12.

15. Poljšak B, Milisav I (2012) Clinical implications of cellular stress responses. Bosn J Basic Med Sci 12: 122-126.

16. Halliwell B, Gutteridge J (1998) Free Radicals in Biology and Medicine. (3rdedn), Oxford, Oxford Science, London, United Kingdom.

17. Azu OO (2012) Highly active antiretroviral therapy (HAART) and testicula morphology: Current status and a case for stereological approach. J Andrology.

18. van Leeuwen E, Wit FW, Repping S, Eeftinck Schattenkerk JK, Reiss P, et al (2008) Effects of antiretroviral therapy on semen quality. AIDS 22: 637-642.

19. Lambert-Niclot S, Poirot C, Tubiana R, Houssaini A, Soulie C, et al. (2011) Effect of antiretroviral drugs on the quality of semen. J Med Virol 83: 1391-1394.

20. Krieger JN, Coombs RW, Collier AC, Koehler JK, Ross SO, et al. (1991) fertility parameters in men infected with human immunodeficiency virus. J Infect Dis 164: 464-469. 
Citation: Azu OO (2012) The Male Genital Tract in the Era of Highly Active Antiretroviral Therapy (HAART): Implication for Antioxidant Therapy. J AIDS Clinic Res 3:169. doi:10.4172/2155-6113.1000169

Page 12 of 16

21. Van der Steeg JW, Steures P, Eijkemans MJ, Habbema JD, Hompes PG, et al. (2007) pregnancy is predictable: a large-scale prospective external validation of the prediction of spontaneous pregnancy in subfertile couples. Hum Reprod 22: $536-542$

22. Basson R (2007) sexuality in chronic illness: no longer ignored. Lancet 369 350-352.

23. Rietschel P, Corcoran C, Stanley T, Basgoz N, Klibanski A, et al. (2000) Prevalence of hypogonadism among men with weight loss related to human immunodeficiency virus infection who were receiving highly active antiretroviral therapy. Clin Infect Dis 31: 1240-1244

24. Agarwal A, Nallella KP, Allamaneni SS, Said TM (2004) Role of antioxidants in treatment of male infertility: an overview of the literature. Reprod Biomed Online 8: 616-627.

25. Hunter RH, Rodriguez-Martinez H (2004) Capacitation of mammalian spermatozoa in vivo, with a specific focus on events in the fallopian tubes. Mol Reprod Dev 67: 243-250.

26. Aitken RJ, Paterson M, Fisher H, Buckingham DW, van Duin M (1995) Redox regulation of tyrosine phosphorylation in human spermatozoa and its role in the control of human sperm function. J Cell Sci 108: 2017-2025.

27. Labbe G, Pessayre D, Fromenty B (2008) Drug-induced liver injury through mitochondrial dysfunction: mechanisms and detection during preclinical safety studies. Fundam Clin Pharmacol 22: 335-353.

28. Nerurkar PV, Shikuma CM, Nerurkar VR (2001) Sterol regulatory elementbinding proteins and reactive oxygen species: potential role in highly-active antiretroviral therapy (HAART)-associated lipodystrophy. Clin Biochem 34 $519-529$

29. Sanocka D, Kurpisz M (2004) Reactive oxygen species and sperm cells. Reprod Biol Endocrinol 2: 12

30. Ngondi JL, Oben J, Forkah DM, Etame LH, Mbanya D (2006) The effect of different combination therapies on oxidative stress markers in HIV infected patients in Cameroon. AIDS Res Ther 3: 19

31. Munoz JF, Salmen S, Berrueta LR, Carlos MP, Cova JA, et al. (1999) Effect of human immunodeficiency virus type 1 on intracellular activation and superoxide production by neutrophils. J Infect Dis 180: 206-210.

32. Gonzalez PK, Doctrow SR, Malfroy B, Fink MP (1997) Role of oxidant stress and iron delocalization in acidosis-induced intestinal epithelial hyperpermeability. Shock 8: 108-114.

33. Garcia-de-la-Asuncion J, Gomez-Cambronero LG, Del Olmo ML, Pallardo FV, Sastre J (2007) Vitamins C and E prevent AZT-induced leukopenia and loss of cellularity in bone marrow. Studies in mice. Free Radic Res 41: 330-334.

34. Biemond P, van Eijk HG, Swaak AJ, Koster JF (1984) Iron mobilization from ferritin by superoxide derived from stimulated polymorphonuclear leukocytes. Possible mechanism in inflammation diseases. J Clin Invest 73: 1576-1579.

35. Burton GW (1994) Vitamin E: molecular and biological function. Proc Nutr Soc 53: $251-262$.

36. Maytin M, Leopold J, Loscalzo J (1999) Oxidant stress in the vasculature. Curr Atheroscler Rep 1: 156-164.

37. Suzuki YJ, Forman HJ, Sevanian A (1997) Oxidants as stimulators of signal transduction. Free Radic Biol Med 22: 269-285.

38. Agarwal A, Saleh RA, Bedaiwy MA (2003) Role of reactive oxygen species in the pathophysiology of human reproduction. Fertil Steril 79: 829-843.

39. Day BJ, Lewis W (2004) Oxidative stress in NRTI-induced toxicity: evidence from clinical experience and experiments in vitro and in vivo. Cardiovasc Toxicol 4: 207-216

40. Azu OO, Duru FIO, Osinubi AA, Oremosu AA, Noronha CC, et al. (2010) Histomorphometric effects of Kigelia africana (Bignoniaceae) fruit extract on the testis following short-term treatment with cisplatin in male Sprague-Dawley rats. Middle East Fertility Society Journal 15: 200-208.

41. Laurent C, Kouanfack C, Koulla-Shiro S, Nkoue N, Bourgeois A, et al. (2004) Effectiveness and safety of a generic fixed-dose combination of nevirapine stavudine and lamivudine in HIV-1-infected adults in Cameroon: open-labe multicentre trial. Lancet 364: 29-34.

42. Allard JP, Aghdassi E, Chau J, Tam C, Kovacs CM, et al. (1998) Effects of vitamin $\mathrm{E}$ and $\mathrm{C}$ supplementation on oxidative stress and viral load in HIVinfected subjects. AIDS 12: 1653-1659.

43. Papadopulos-Eleopulos E, Hedland-Thomas B, Causer DA (1991) Changes in thiols and glutamate as consequences of simian immunodeficiency virus infection. Lancet 338: 1013-1014.

44. Le Tortorec A, Dejucq-Rainsford N (2010) HIV infection of the male genital tract--consequences for sexual transmission and reproduction. Int J Androl 33 e98-e108

45. Lowe SH, Sankatsing SU, Repping S, van der Veen F, Reiss P, et al. (2004) Is the male genital tract really a sanctuary site for HIV? Arguments that it is not AIDS 18: 1353-1362

46. Kashuba AD, Dyer JR, Kramer LM, Raasch RH, Eron JJ, et al. (1999) Antiretroviral-drug concentrations in semen: Implications for sexual transmission of human immunodeficiency virus type 1. Antimicrob Agents Chemother 43: 1817-1826

47. Kushnir VA, Lewis W (2011) Human immunodeficiency virus/acquired immunodeficiency syndrome and infertility: emerging problems in the era of highly active antiretrovirals. Fertil Steril 96: 546-553.

48. Apostolova N, Gomez-Sucerquia LJ, Moran A, Alvarez A, Blas-Garcia A, et al (2010) Enhanced oxidative stress and increased mitochondrial mass during efavirenz-induced apoptosis in human hepatic cells. Br J Pharmacol 160: 20692084.

49. Skuta G, Fischer GM, Janaky T, Kele Z, Szabo P, et al. (1999) Molecular mechanism of the short-term cardiotoxicity caused by $2^{\prime}, 3^{\prime}$-dideoxycytidine (ddC): modulation of reactive oxygen species levels and ADP-ribosylation reactions. Biochem Pharmacol 58: 1915-1925.

50. Szabados E, Fischer GM, Toth K, Csete B, Nemeti B, et al. (1999) Role of reactive oxygen species and poly-ADP-ribose polymerase in the development of AZT-induced cardiomyopathy in rat. Free Radic Biol Med 26: 309-317.

51. McLemore JL, Beeley P, Thorton K, Morrisroe K, Blackwell W, et al. (1998) Rapid automated determination of lipid hydroperoxide concentrations and total antioxidant status of serum samples from patients infected with HIV: elevated lipid hydroperoxide concentrations and depleted total antioxidant capacity of serum samples. Am J Clin Pathol 109: 268-273.

52. Anthony H. Kashou, Ashok Agarwal (2011) oxidants and antioxidants in the pathogenesis of HIVIAIDS. The Open Reproductive Science Journal 3: 154 161.

53. Jaruga P, Jaruga B, Gackowski D, Olczak A, Halota W, et al. (2002) Supplementation with antioxidant vitamins prevents oxidative modification of DNA in lymphocytes of HIV-infected patients. Free Radic Biol Med 32: 414-420.

54. Pinti M, Salomoni P, Cossarizza A (2006) Anti-HIV drugs and the mitochondria. Biochim Biophys Acta 1757: 700-707.

55. Lewis W, Copeland WC, Day BJ (2001) Mitochondrial DNA depletion, oxidative stress, and mutation: mechanisms of dysfunction from nucleoside reverse transcriptase inhibitors. Lab Invest 81: 777-790.

56. Schapira AH, Cooper JM (1992) Mitochondrial function in neurodegeneration and ageing. Mutat Res 275: 133-143.

57. Foli A, Benvenuto F, Piccinini G, Bareggi A, Cossarizza A, et al. (2001) Direct analysis of mitochondrial toxicity of antiretroviral drugs. AIDS 15: 1687-1694.

58. Walker UA, Setzer B, Venhoff N (2002) Increased long-term mitochondria toxicity in combinations of nucleoside analogue reverse-transcriptase inhibitors. AIDS 16: 2165-2173.

59. Lopez S, Miro O, Martinez E, Pedrol E, Rodriguez-Santiago B, et al. (2004) Mitochondrial effects of antiretroviral therapies in asymptomatic patients. Antivi Ther 9: 47-55.

60. Lewis W, Day BJ, Copeland WC (2003) Mitochondrial toxicity of NRTI antiviral drugs: an integrated cellular perspective. Nat Rev Drug Discov 2: 812-822.

61. Matarrese P, Gambardella L, Cassone A, Vella S, Cauda R, et al. (2003) Mitochondrial membrane hyperpolarization hijacks activated $T$ lymphocytes toward the apoptotic-prone phenotype: homeostatic mechanisms of HIV protease inhibitors. J Immunol 170: 6006-6015.

62. Matarrese P, Tinari A, Gambardella L, Mormone E, Narilli P, et al. (2005) HIV protease inhibitors prevent mitochondrial hyperpolarisation and redox imbalance and decrease endogenous uncoupler protein-2 expression in gp 120-activated human T lymphocytes. Antivir Ther 10: M29-M45. 
Citation: Azu OO (2012) The Male Genital Tract in the Era of Highly Active Antiretroviral Therapy (HAART): Implication for Antioxidant Therapy. J AIDS Clinic Res 3:169. doi:10.4172/2155-6113.1000169

63. Somasundaran M, Zapp ML, Betaie LK, Pang L, Byron KS, et al. (1994) Localization of HIV RNA in mitochondria of infected cells: Potential role in cytopathogenicity. J Cell Biol 126: 1353-1360.

64. Wallace DC (1999) Mitochondrial diseases in man and mouse. Science 283: $1482-1488$.

65. Mondal D, Pradhan L, Ali M, Agrawal KC (2004) HAART drugs induce oxidative stress in human endothelial cells and increase endothelial recruitment of mononuclear cells: exacerbation by inflammatory cytokines and amelioration by antioxidants. Cardiovasc Toxicol 4: 287-302

66. Kline ER, Bassit L, Hernandez-Santiago BI, Detorio MA, Liang B, et al. (2009) Long-term exposure to AZT, but not d4T, increases endothelial cell oxidative stress and mitochondrial dysfunction. Cardiovasc Toxicol 9: 1-12.

67. Yamaguchi T, Katoh I, Kurata S (2002) Azidothymidine causes functional and structural destruction of mitochondria, glutathione deficiency and HIV-1 promoter sensitization. Eur J Biochem 269: 2782-2788.

68. Manda KR, Banerjee A, Banks WA, Ercal N (2011) Highly active antiretrovira therapy drug combination induces oxidative stress and mitochondrial dysfunction in immortalized human blood-brain barrier endothelial cells. Free Radic Biol Med 50: 801-810.

69. Boveris A, Chance B (1973) The mitochondrial generation of hydrogen peroxide. General properties and effect of hyperbaric oxygen. Biochem J 134 707-716.

70. Esposito LA, Melov S, Panov A, Cottrell BA, Wallace DC (1999) Mitochondria disease in mouse results in increased oxidative stress. Proc Natl Acad Sci USA 96: $4820-4825$

71. Taylor DE, Ghio AJ, Piantadosi CA (1995) Reactive oxygen species produced by liver mitochondria of rats in sepsis. Arch Biochem Biophys 316: 70-76.

72. Lin MT, Beal MF (2006) Mitochondrial dysfunction and oxidative stress in neurodegenerative diseases. Nature 443: 787-795.

73. Mattson DM, Ahmad IM, Dayal D, Parsons AD, Aykin-Burns N, et al. (2009) Cisplatin combined with zidovudine enhances cytotoxicity and oxidative stress in human head and neck cancer cells via a thiol-dependent mechanism. Free Radic Biol Med 46: 232-237.

74. Buckley BJ, Tanswell AK, Freeman BA (1987) Liposome-mediated augmentation of catalase in alveolar type II cells protects against $\mathrm{H}_{2} \mathrm{O}_{2}$ injury. $J$ Appl Physiol 63: 359-367.

75. Marinho HS, Antunes F, Pinto RE (1997) Role of glutathione peroxidase and phospholipid hydroperoxide glutathione peroxidase in the reduction of lysophospholipid hydroperoxides. Free Rad Biol Med 22: 871-883.

76. Halliwell B, Gutteridge JM (1985) The importance of free radicals and catalytic metal ions in human diseases. Mol Aspects Med 8: 89-193.

77. Lim SE, Longley MJ, Copeland WC (1999) The mitochondrial p55 accessory subunit of human DNA polymerase gamma enhances DNA binding, promotes processive DNA synthesis, and confers $\mathrm{N}$-ethylmaleimide resistance. J Bio Chem 274: 38197-38203

78. Wang D, Kreutzer DA, Essigmann JM (1998) Mutagenicity and repair of oxidative DNA damage: insights from studies using defined lesions. Mutat Res 400: 99-115.

79. Lewis W, Dalakas MC (1995) Mitochondrial toxicity of antiviral drugs. Nat Med 1: 417-422.

80. Kakuda TN, Brundage RC, Anderson PL, Fletcher CV (1999) Nucleoside reverse transcriptase inhibitor-induced mitochondrial toxicity as an etiology for lipodystrophy. AIDS 13: 2311-2312.

81. Beckman JS, Koppenol WH (1996) Nitric oxide, superoxide, and peroxynitrite: the good, the bad, and ugly. Am J Physiol 271: 1424-1437.

82. Radi R, Beckman JS, Bush KM, Freeman BA (1991) Peroxynitrite-induced membrane lipid peroxidation: the cytotoxic potential of superoxide and nitric oxide. Arch Biochem Biophys 288: 481-487.

83. Foster MH (2004) Taking HAART in HIVAN: will protease inhibitor sparing regimens alter renal outcome? Kidney Int 65: 1105-1106.

84. Slater AF, Nobel CS, Orrenius S (1995) The role of intracellular oxidants in apoptosis. Biochem Biophys Acta 1271: 59-62.
85. Brawn K, Fridovich I (1981) DNA strand scission by enzymically generated oxygen radicals. Arch Biochem Biophys 206: 414-419.

86. Yakes FM, Van Houten B (1997) Mitochondrial DNA damage is more extensive and persists longer than nuclear DNA damage in human cells following oxidative stress. Proc Natl Acad Sci USA 94: 514-519.

87. Hall ET, Yan JP, Melancon P, Kuchta RD (1994) 3'-Azido-3'-deoxythymidine potently inhibits protein glycosylation. A novel mechanism for AZT cytotoxicity. J Biol Chem 269: 14355-14358.

88. Varanasi SS, Francis RM, Berger CE, Papiha SS, Datta HK (1999) Mitochondria DNA deletion associated oxidative stress and severe male osteoporosis Osteoporos Int 10: 143-149.

89. Droge W, Eck HP, Mihm S (1994) Oxidant-antioxidant status in human immunodeficiency virus infection. Methods Enzymol 233: 594-601.

90. Aitio ML (2006) N-acetylcysteine -- passe-partout or much ado about nothing? Br J Clin Pharmacol 61: 5-15.

91. Dobmeyer TS, Findhammer S, Dobmeyer JM, Klein SA, Raffel B, (1997) Ex vivo induction of apoptosis in lymphocytes is mediated by oxidative stress: role for lymphocyte loss in HIV infection. Free Radic Biol Med 22: 775-785.

92. Williams MS, Henkart PA (1996) Role of reactive oxygen intermediates in TCR induced death of T cell blasts and hybridomas. J Immunol 157: 2395-2402.

93. Israel N, Gougerot-Pocidalo MA (1997) Oxidative stress in human immunodeficiency virus infection. Cell Mol Life Sci 53: 864-870.

94. Hsu PC, Liu MY, Hsu CC, Chen LY, Guo YL (1998) Effects of Vitamin E and/or $\mathrm{C}$ on reactive oxygen species-related lead toxicity in the rat sperm. Toxicology 128: 169-179.

95. Henry K, Chinnock BJ, Quinn RP, Fletcher CV, de Miranda P, et al. (1988) Concurrent zidovudine levels in semen and serum determined by radioimmunoassay in patients with AIDS or AIDS-related complex. JAMA 259 3023-3026.

96. Eron JJ, Vernazza PL, Johnston DM, Seillier-Moiseiwitsch F, Alcorn TM, e al. (1998) Resistance of HIV-1 to antiretroviral agents in blood and seminal plasma: implications for transmission. AIDS 12: 181-189.

97. Taylor S, Back DJ, Drake SM, Workman J, Reynolds H, et al. (2001) Antiretrovira drug concentrations in semen of HIV-infected men: differential penetration of indinavir, ritonavir and saquinavir. J Antimicrob Chemother 48: 351-354.

98. Folgero T, Bertheussen K, Lindal S, Torbergsen T, Oian P (1993) Mitochondria disease and reduced sperm motility. Hum Reprod 8: 1863-1868.

99. Ruiz-Pesini E, Diez C, Lapena AC, Perez-Martos A, Montoya J, et al. (1998) Correlation of sperm motility with mitochondrial enzymatic activities. Clin Chem 44: $1616-1620$

100. Donnelly ET, O'Connell M, McClure N, Lewis SE (2000) Differences in nuclea DNA fragmentation and mitochondrial integrity of semen and prepared human spermatozoa. Hum Reprod 15: 1552-1561.

101. May-Panloup P, Chretien MF, Savagner F, Vasseur C, Jean M, et al. (2003) ncreased sperm mitochondrial DNA content in male infertility. Hum Reprod 18: 550-556.

102. Johns DR (1995) Seminars in medicine of the Beth Israel Hospital, Boston Mitochondrial DNA and disease. N Engl J Med 333: 638-644.

03. Brinkman K, ter Hofstede HJ, Burger DM, Smeitink JA, Koopmans PP (1998) Adverse effects of reverse transcriptase inhibitors: mitochondrial toxicity as common pathway. AIDS 12: 1735-1744

104.White DJ, Mital D, Taylor S, St John AC (2001) Sperm mitochondrial DNA deletions as a consequence of long term highly active antiretroviral therapy. AIDS 15: 1061-1062.

105.Xia S, Rosen EM, Laterra J (2005) Sensitization of Glioma Cells to FasDependent apoptosis by chemotherapy-induced oxidative stress. Cancer Res 65: 5248-5255.

106. Boekelheide K (2005) Mechanisms of toxic damage to spermatogenesis. J Natl Cancer Inst Monogr 34: 6-8.

107.Baum MK, Shor-Posner G, Lai S, Zhang G, Lai H, et al. (1997) High risk of HIV-related mortality is associated with selenium deficiency. J Acquir Immune Defic Syndr Hum Retrovirol 15: 370-374.

108. Tang AM, Graham NM, Saah AJ (1996) Effects of micronutrient intake on 
Citation: Azu OO (2012) The Male Genital Tract in the Era of Highly Active Antiretroviral Therapy (HAART): Implication for Antioxidant Therapy. J AIDS Clinic Res 3:169. doi:10.4172/2155-6113.1000169

survival in human immunodeficiency virus type 1 infection. Am J Epidemiol 143: $1244-1256$

109. Chan G, Collins J, Horn T (1997) Antioxidants may still have a role in HIV treatment. GMHC Treat Issues 11: 6-12.

110. Muller F, Svardal AM, Nordoy I, Berge RK, Aukrust P, et al. (2000) Virologica and immunological effects of antioxidant treatment in patients with HIV infection. Eur J Clin Invest 30: 905-914

111. Lee LS, Andrade AS, Flexner C (2006) Interactions between natural health products and antiretroviral drugs: pharmacokinetic and pharmacodynamic effects. Clin Infect Dis 43: 1052-1059.

112. Slain D, Amsden JR, Khakoo RA, Fisher MA, Lalka D, et al. (2005) Effect of high-dose Vitamin $C$ on the steady-state pharmacokinetics of the protease inhibitor indinavir in healthy volunteers. Pharmacotherapy 25: 165-170.

113. Papparella I, Ceolotto G, Berto L, Cavalli M, Bova S, et al. (2007) Vitamin C prevents zidovudine-induced $\mathrm{NAD}(\mathrm{P}) \mathrm{H}$ oxidase activation and hypertension in the rat. Cardiovasc Res 73: 432-438.

114. Burbano X, Miguez-Burbano MJ, McCollister K, Zhang G, Rodriguez A, et al. (2002) Impact of a Selenium Chemoprevention Clinical Trial on Hospital Admissions of HIV-Infected Participants. HIV Clin Trials 3: 483-491.

115. Bjugstad KB, Flitter WD, Garland WA, Su GC, Arendash GW (1998) Preventive actions of a synthetic antioxidant in a novel animal model of AIDS dementia. Brain Res 795: 349-357.

116. Halliwell B (1991) Reactive oxygen species in living systems: source, biochemistry and role in human disease. Am J Med 91: 14S-22S.

117. Jones DP, Kagan VE, Aust SD, Reed DJ, Omaye ST (1995) Impact of nutrients on cellular lipid peroxidation and antioxidant defense system. Fundam Appl Toxicol 26: 1-7.

118. Comhaire FH, Christophe AB, Zalata AA, Dhooge WS, Mahmoud AM, et al (2000) The effects of combined conventional treatment, oral antioxidants and essential fatty acids on sperm biology in subfertile men. Prostaglandins Leukot Essent Fatty Acids 63: 159-165.

119. Menezo YJ, Hazout A, Panteix G, Robert F, Rollet J, et al. (2007) Antioxidants to reduce sperm DNA fragmentation: an unexpected adverse effect. Reprod Biomed Online 14: 418-421.

120. Ho DD, Neumann AU, Perelson AS, Chen W, Leonard JM, et al. (1995) Rapid turnover of plasma virons and CD4 lymphocytes in HIV-1 infection. Nature 373: $123-126$

121. Iqbal K, Khan A, Khattak MMAK (2004) Biological Significance of Ascorbic Acid (Vitamin C) in Human Health-A Review. Pakistan Journal of Nutrition 3: 5-13.

122. Evans HM, Bishop KS (1922) On the existence of a hitherto unrecognized dietary factor essential for reproduction. Science 56: 650-651.

123. Burton GW, Joyce A, Ingold KU (1983) Is vitamin E the only lipid-soluble, chainbreaking antioxidant in human blood plasma and erythrocyte membranes? Arch Biochem Biophys 221: 281-290.

124. Ingold KU, Webb AC, Witter D, Burton GW, Metcalfe TA, et al. (1987) Vitamin $E$ remains the major lipid-soluble, chain-breaking antioxidant in human plasma even in individuals suffering severe vitamin E deficiency. Arch Biochem Biophys 259: 224-225

125. Mason KE (1933) Differences in testis injury and repair after vitamin A deficiency, vitamin $E$ deficiency and inanition. Am J Anatomy 52: 153-239.

126. Malvy DJ, Richard MJ, Arnaud J, Favier A, Amedee-Manesme O (1994) Relationship of plasma malondialdehyde, vitamin $E$ and antioxidant micronutrients to human immunodeficiency virus-1 seropositivity. Clin Chim Acta 224: 89-94.

127. Kagan VE, Serbinova EA, Packer L (1990) Generation and recycling of radicals from phenolic antioxidants. Arch Biochem Biophys 280: 33-39.

128. Pacht ER, Diaz P, Clanton T, Hart J, Gadek JE (1997) Serum vitamin E decreases in HIV-seropositive subjects over time. J Lab Clin Med 130: 293296.

129. Abrams B, Duncan D, Hertz-Picciotto I (1993) A prospective study of dietary intake and acquired immune deficiency syndrome in HIV-seropositive homosexual men. J Acquir Immune Defic Syndr 6: 949-958.
130. Geissler RG, Ganser A, Ottmann OG, Gute P, Morawetz A, et al. (1994) In vivo improvement of bone marrow-derived hematopoetic colony formation in HIVpositive patients by alpha-D-tocopherol and erythropoietin. Eur J Haematol 53: 201-206.

131. Paulik M, Lancaster M, Croom D, Spencer D, Weiel J, et al. (2000) Antioxidants rescue NRTI-induced metabolic changes in AKR/J mice. Antivir Ther 5: 6.

132. Tengerdy RP (1990) The role of vitamin $E$ in immune response and disease resistance. Ann N Y Acad Sci 587: 24-33.

133. Suzuki YI, Packer L (1993) Inhibition of NF-kappa B activation by vitamin $E$ derivatives. Biochem Biophys Res Commun 193: 277-283.

134. Baeuerle PA, Henkel T (1994) Function and activation of NF-kappa B in the immune system. Annu Rev Immunol 12: 141-179.

135. Packer L (1991) Protective role of vitamin E in biological systems. Am J Clin Nutr 53: 1050S-1055S.

136. Packer L, Suzuki YJ (1993) Vitamin E and alpha-lipoate: role in antioxidant recycling and activation of NF-kappa $B$ transcription factor. Mol Aspects Med 14: 229-239.

137. Devaraj S, Jialal | (1999) Alpha-tocopherol decreases interleukin-1 beta release from activated human monocytes by inhibition of 5-lipoxygenase. Arterioscler Thromb Vasc Biol 19: 1125-1133

138. Bendich A (1990) Antioxidant micronutrients and immune responses. In Bendich A, Chandra RK (Edn). Micronutrients and immune functions. N.Y Academy of Sciences, NY. 175.

139. Castellini C, Lattaioli P, Dal Bosco A, Minelli A, Mugnai C (2003) Oxidative status and semen characteristics of rabbit buck as affected by dietary vitamin E, C and n-3 fatty acids. Reprod Nutr Dev 43: 91-103.

140.Stephensen CB, Marquis GS, Jacob RA, Kruzich LA, Douglas SD, et al. (2006) Vitamins $C$ and $E$ in adolescents and young adults with HIV infection. Am J Clin Nutr 83: 870-879.

141. Fraga CG, Motchnik PA, Shigenaga MK, Helbock HJ, Jacob RA, et al. (1991) Ascorbic acid protects against endogenous oxidative DNA damage in human sperm. Proc Natl Acad Sci USA 88: 11003-11006.

142.Dawson EB, Harris WA, Teter MC, Powell LC (1992) Effect of ascorbic acid supplementation on the sperm quality of smokers. Fertil Steril 58: 1034-1039.

143. Bobyrev VN, Vese'Iskil ISh, Bobyreva LE (1989) Antioxidants in the prevention and treatment of cerebral arteriosclerosis. Zh Nevropatol Psikhiatr Im S S Korsakova 89: 60-63.

144. Obirikorang C, Yeboah FA, Quaye L (2010) Antioxidant therapy- A relevan therapeutic adjunct for antiretroviral therapy in Plwhas in Ghana. Webmed Central Infectious Diseases 1: WMC001039.

145. Duthie, SJ, Ma AG, Ross MA, Collins AR (1996) Antioxidant supplementation decreases oxidative DNA damage in human lymphocytes. Cancer Res 56 1291-1295.

146. Podmore ID, Griffiths HR, Herbert KE, Mistry N, Mistry P, et al (1998) Vitamin C exhibits pro-oxidant properties. Nature 392: 559.

147. Carty JL, Bevan R, Waller H, Mistry N, Cooke M, et al. (2000) The effects of vitamin $\mathrm{C}$ supplementation on protein oxidation in healthy volunteers. Biochem Biophys Res Commun 273: 729-735.

148. Odeleye OE, Watson RR (1991) The potential role of vitamin $E$ in the treatment of immunologic abnormalities during acquired immune deficiency syndrome. Prog Food Nutr Sci 15: 1-19.

149. Semba RD, Graham NMH, Caiaffa WT, Margolick JB, Clement L, et al (1993) Increased mortality associated with vitamin A deficiency during human immunodeficiency virus type 1 infection. Arch Intern Med 153: 2149-2154.

150. Semba RD, Miotti PG, Chiphangwi JD, Saah AJ, Canner JK, et al. (1994) Maternal vitamin A deficiency and mother-to-child transmission of HIV-1. ancet 343: 1593-1597.

151. Mgbekem MA, ME John, IB Umoh, EU Eyong, N Ukam, BD Omotola (2011) Plasma antioxidant micronutrients and oxidative stress in people living with HIV. Pakistan Journal of Nutrition 10: 214-219.

152. Silveira SA, Figueiredo JF, Jordao Junior A, de Unamuno MD, Rodrigues M de $L$, et al. (1999) Malnutrition and hypovitaminosis A in AIDS patients. Rev Soc Bras Med Trop 32: 119-124. 
Citation: Azu OO (2012) The Male Genital Tract in the Era of Highly Active Antiretroviral Therapy (HAART): Implication for Antioxidant Therapy. J AIDS Clinic Res 3:169. doi:10.4172/2155-6113.1000169

153. Ullrich R, Zeitz M, Heise W, L'age M, Höffken G, et al. (1989) Small intestinal structure and function in patients infected with HIV: evidence for HIV-induced enteropathy. Ann Intern Med 111: 15-21

154. Jimenez-Exposito MJ, Garcia-Lorda P, Alonso-Villaverde C, de Virgala CM Sola R, et al. (1998) Effect of malabsorption on nutritional status and resting energy expenditure in HIV-infected patients. AIDS 12: 1965-1972.

155. Chiu HJ, Fischman DA, Hammerling U (2008) Vitamin A depletion causes oxidative stress, mitochondrial dysfunction and PARP-1 dependent energy deprivation. FASEB J 22: 3878-3387.

156. Tang AM, Graham NM, Semba RD, Saah AJ (1997) Association between serum vitamin $A$ and $E$ levels and HIV-1 disease progression. AIDS 11: 613620.

157. Niki E, Noguchi N, Tsuchihashi H, Gotoh N (1995) Interaction among vitamin C, vitamin E and beta-carotein. Am J Clin Nutr 62: 1322-1326.

158. Edge R, DJ McGarvey, TG Truscott (1997) The carotenoids as anti-oxidants a review. J Photochem Photobiol B 41: 189-200.

159. Siems W, Sommerburg O, Schild L, Augustine W, Langhans CD, et al. (2002) beta-carotene cleavage products induce oxidative stress in vitro by impairing mitochondrial respiration. FASEB J 16: 1289-1291.

160. Atkuri KR, Mantovani JJ, Herzenberg LA, Herzenberg LA (2007) $\mathrm{N}$-acetylcysteine-a safe antidote for cysteine/glutathione deficiency. Curr Opin Pharmacol 7: 355-359

161. Halliwell B (1996) Antioxidants in human health and disease. Annu Rev Nutr 16: 33-50.

162. Bonanomi L, Gazzaniga A (1980) Toxicological, pharmacokinetic and metabolic studies on acetylcysteine. Eur J Respir Dis Suppl 111: 45-51.

163. Spada C, Treitinger A, Reis M, Masokawa IY, Verdi JC, et al. (2002) The effect of $\mathrm{N}$-acetylcysteine supplementation upon viral load, CD4, CD8, total lymphocyte count and hematocrit in individuals undergoing antiretrovira treatment. Clin Chem Lab Med 40: 452-455.

164.Ledru E, Christeff N, Patey O, de Truchis P, Melchior JC, et al. (2000) Alteration of tumour necrosis factor-alpha T-cell homeostasis following potent antiretroviral therapy: contribution to the development of human immunodeficiency virus-associated lipodystrophy syndrome. Blood 95: 3191 3198

165. Moreno-Manzano V, Ishikawa Y, Lucio-Cazana J, Kitamura M (2000) Selective involvement of superoxide anion, but not downstream compounds hydrogen peroxide and peroxynitrite, in tumour necrosis factor-alpha-induced apoptosis of rat mesangial cells. J Biol Chem 275: 12684-12691.

166. Semba RD, Tang AM (1999) Micronutrients and the pathogenesis of human immunodeficiency virus infection. Br J Nutr 81: 181-189.

167. Fawzi WW (2003) Micronutrients and human immunodeficiency virus type 1 disease progression among adults and children. Clin Infect Dis 37: 112-116.

168. Irlam JH, Visser ME, Rollins N, Siegfried N (2005) Micronutrient supplementation in children and adults with HIV infection. Cochrane Database Syst Rev CD003650.

169. Eley BS, Sive AA, Abelse L, Kossew G, Cooper M, et al. (2002) Growth and micronutrient disturbances in stable, HIV-infected children in Cape Town. Ann Trop Paediatr 22: 19-23.

170. Miller TL, Agostoni C, Duggan C, Guarino A, Manary M, et al. (2008) Gastrointestinal and Nutritional Complications of Human Immunodeficiency Virus Infection. J Pediatr Gastroenterol Nutr 47: 247-253.

171. Cirelli A, Ciard M, DeSimone C, Sorice F, Giordano R, et al. (1991) Serum selenium concentration and disease progress in patients with HIV infection. Clin Biochem 24: 211-214.

172. Beck MA (1999) Selenium and host defense towards viruses. Proc Nutr Soc 58: 707-711.

173. Levander OA, Beck MA (1999) Selenium and viral virulence. Br Med Bul 55 528-533.

174. Look MP, Rockstroh JK, Rao GS, Kreuzer KA, Spengler U, et al. (1997) Serum selenium versus lymphocyte subsets and markers of disease progression and inflammatory response in human immunodeficiency virus-1 infection. Bio Trace Elem Res 56: 31-41.
175. Kiremidjian-Schumacher L, Roy M (1998) Selenium and immune function. Z Ernhrungswiss 37: 50-56.

176. Look MP, Rockstroh JK, Rao GS, Kreuzer KA, Barton S, et al. (1997) Serum selenium, plasma glutathione (GSH) and erythrocyte glutathione peroxidase (GSH-Px)-levels in asymptomatic versus symptomatic human immunodeficiency virus-1 (HIV-1)-infection. Eur J Clin Nutr 51: 266-272.

177. Girodon F, Lombard M, Galan P, Brunet-Lecomte P, Monget AL, et al. (1997) Effect of micronutrient supplementation on infection in institutionalized elderly subjects: a controlled trial. Ann Nutr Metab 41: 98-107.

178. Girodon F, Galan P, Monget AL, Boutron-Ruault MC, Brunet-Lecomte P, et al (1999) Impact of trace elements and vitamin supplementation on immunity and infections in institutionalized elderly patients: a randomized controlled trial. MIN. VIT. AOX. Geriatric network. Arch Intern Med 159: 748-754.

179. Shor-Posner G, Lecusay R, Morales G, Campa A, Miguez-Burbano MJ (2002) Neuroprotection in HIV-Positive Drug Users: Implications for Antioxidant Therapy. JAIDS Journal of Acquired Immune Deficiency Syndromes 31: 84-88

180.Lee J, Yoshikawa K, Watson RR (1999) Nutritional Deficiencies in AIDS patients: A treatment Opportunity. In AIDS and Complementary and Alternative Medicine. Bastyr Research 56-70.

181. Taylor EW, Ramanathan CS, Jalluri RK, Nadimpalli RG (1994) A basis for new approaches to the chemotherapy of AIDS: novel genes in HIV-1 potentially encode selenoproteins expressed by ribosomal frameshifting and termination suppression. J Med Chem 37: 2637-2654.

182. Scott R, MacPherson A, Yates RW, Hussain B, Dixon J (1998) The effect of oral selenium supplementation on human sperm motility. $\mathrm{Br} \mathrm{J}$ Urol 82: 76-80.

183. Iwanier K, Zachara BA (1995) Selenium supplementation enhances the element concentration in blood and seminal fluid but does not change the spermatozoal quality characteristics in subfertile men. J Androl 16: 441-447.

184. Hawkes WC, Turek PJ (2001) Effects of dietary selenium on sperm motility in healthy men. J Androl J Androl 22: 764-772.

185. Tramer F, Rocco F, Micali F, Sandri G, Panfili E (1998) Antioxidant systems in rat epididymal spermatozoa. Biol Reprod 59: 753-758.

186. Twigg J, Fulton N, Gomez E, Irvine DS, Aitken RJ (1998) Analysis of the impact of intracellular reactive oxygen species generation on the structural and functional integrity of human spermatozoa: lipid peroxidation, DNA fragmentation and effectiveness of antioxidants. Hum Reprod 13: 1429-1436.

187.Saez F, Motta C, Boucher D, Grizard G. (1998) Antioxidant capacity of prostasomes in human semen. Mol Hum Reprod 4: 667-672.

188. Tremellen K (2008) Oxidative stress and male infertility-a clinical perspective. Human Reproduction Update 14: 243-258.

189.Delmas-Beauvieux MC, Peuchant E, Couchouron A, Constans J, Sergeant C, et al. (1996) The enzymatic antioxidant system in blood and glutathione status in human immunodeficiency virus (HIV)-infected patients: effects of supplementation with selenium or b-carotene. Am J Clin Nutr 64: 101-107.

190. Fujii J, luchi Y, Matsuki S, Ishii T (2003) Cooperative function of antioxidant and redox systems against oxidative stress in male reproductive tissues. Asian J Androl 5: 1-12

191. Meister A (1995) Glutathione metabolism. Meth Enzymol 251: 3-7.

192. Roederer M, Ela SW, Staal FJT, Herzenberg LA, Herzenberg LA (1992) N-Acetylcysteine: A New Approach to Anti-HIV Therapy. AIDS Res Hum Retroviruses 8: 209-217.

193. Cirelli A, Ciardi M, de Simone C, Sorice F, Giordano R, et al. (1991) Serum selenium concentration and disease progress in patients with HIV infection. Clin Biochem 24: 211-214.

194. Stehbens WE (2004) Oxidative stress in viral hepatitis and AIDS. Exp Mol Pathol 77: 121-132

195. Cathcart RF (1985) Vitamin C: the nontoxic, nonrate-limited, antioxidant free radical scavenger. Med Hypotheses 18: 61-77.

196. Sundaram M, Saghayam S, Priya B, Venkatesh KK, Balakrishnan P, et al. (2008) Changes in antioxidant profile among HIV-infected individuals on generic highly active antiretroviral therapy in southern India. Int $\mathrm{J}$ Infect Dis 12: 61-66.

197.Lenzi A, Picardo M, Gandini L, Lombardo F, Terminali O, et al. (1994) 
Citation: Azu OO (2012) The Male Genital Tract in the Era of Highly Active Antiretroviral Therapy (HAART): Implication for Antioxidant Therapy. J AIDS Clinic Res 3:169. doi:10.4172/2155-6113.1000169

Page 16 of 16

Glutathione treatment of dyspermia: effect on the lipoperoxidation process. Hum Reprod 9: 2044-2050.

198.Dworkin BM, Wormser GP, Axelrod F, Pierre N, Schwarz E, et al. (1990) Dietary intake in patients with AIDS, patients with AIDS-related complex and serologically positive HIV patients: correlations with nutritional status. JPEN J Parenter Enteral Nutr 14: 605-609.

199. Ikeda M, Kodama H, Fukuda J, Shimizu Y, Murata M, et al. (1999) Role of radical oxygen species in rat testicular germ cell apoptosis induced by heat stress. Biol Reprod 61: 393-399.

200. Adaramoye OA, Adesanya OA, Adewumi OM and Akanni O (2012) Studies on the toxicological effect of nevirapine, an antiretroviral drug on the liver, kidney and testis of male Wistar rats. Hum Exp Toxicol 31: 676-685.

201. Vernet P, Aitken RJ, Drevet JR (2004) Antioxidant strategies in the epididymidis. Mol Cell Endocrinol 216: 31-39.

202. MacLeod J (1943) The role of oxygen in the metabolism and motility of human spermatozoa. Am J Physiol 138: 512-518.

203. Chen H, Chow PH, So KC, Cheung ALM, Cheng LY, et al. (2003) Male genital antioxidant enzymes: their source, function in the female, and ability to preserve sperm DNA integrity in the golden hamster. J Androl 21: 704-711.

204. Mandas A, lorio EL, Congiu MG, Balestrieri C, Mereu A, et al. (2009) Oxidative Imbalance in HIV-1 infected Patients Treated with Antiretroviral Therapy. J Biomed Biotechnol.

205. Ben-Romano R, Rudich A, Etzion S, Potashnik R, Kagan E, et al. (2006) Nelfinavir induces adipocyte insulin resistance through the induction of oxidative stress: differential protective effect of antioxidant agents. Antivir Ther 11: 1051-1060.
206. Awodele O, Olayemi SO, Nwite JA, Adeyemo TA (2012) Investigation of the levels of oxidative stress parameters in HIV and HIV-TB co-infected patients. J Infect Dev Ctries 6: 79-85

207. Ahmad G, Moinard N, Jouanolou V, Daudin M, Gandia P, et al. (2011) In vitro assessment of the adverse effects of antiretroviral drugs on the human male gamete. Toxicol In Vitro 25: 485-491.

208. Fawzi WW, Msamanga GI, Spiegelman D, Wei R, Kapiga S, et al. (2004) A randomized trial of multivitamin supplements and HIV Disease Progression and Mortality. Hunter. N Engl J Med 351: 23-32.

209. Fridovich I (1995) Superoxide radical and superoxide dismutases. Annu Rev Biochem 64: 97-112.

210. Mills GC (1957) Hemoglobin catabolism I. Glutathione peroxidase, an erythrocyte enzyme which protects hemoglobin from oxidative breakdown. $J$ Biol Chem 229: 189-197.

211. Loew O (1900) A new enzyme of general occurrence in organisms. Science 11: 701-702.

212. Burns JJ (1959) Biosynthesis of L-ascorbic acid; basic defect in scurvy. Am J Med 26: 740-748.

213. Cheeseman KH, Burton GW, Ingold KU, Slater TF (1984) Lipid peroxidation and lipid antioxidants in normal tumor cells. Toxicol Pathol 12: 235-239.

214. Olson JA (1999) Carotenoids and human health. Arch Latinoam Nutr 49: 7S-11S.

215.Spallholz JE (1994) On the nature of selenium toxicity and carcinostatic activity. Free Radic Biol Med 17: 45-64. 